\title{
Panic-Prone State Induced in Rats with GABA Dysfunction in the Dorsomedial Hypothalamus Is Mediated by NMDA Receptors
}

\author{
Philip L. Johnson and Anantha Shekhar \\ Department of Psychiatry, Indiana University School of Medicine, Indianapolis, Indiana 46202
}

\begin{abstract}
Rats with chronic inhibition of GABA synthesis and consequently enhanced glutamatergic excitation in the dorsomedial hypothalamus (DMH) develop panic-like responses, defined as tachycardia, tachypnea, hypertension, and increased anxiety as measured by a social interaction (SI) test, after intravenous sodium lactate infusions, a phenomenon similar to patients with panic disorder. Therefore, the present studies tested the role of the postsynaptic NMDA and AMPA type glutamatergic receptors in the lactate-induced panic-like responses in these rats. Rats were fit with femoral arterial and venous catheters and Alzet pumps [filled with the GABA synthesis inhibitor L-allylglycine (L-AG; $3.5 \mathrm{nmol} / 0.5 \mu$ l per hour) or its inactive isomer D-AG] into the DMH. After $4-5 \mathrm{~d}$ of recovery only those rats with $\mathrm{L}-\mathrm{AG}$ pumps exhibited panic-like responses to lactate infusions. Using double immunocytochemistry, we found that rats exhibiting panic-like responses (e.g., L-AG plus lactate) had increased c-Fos immunoreactivity in DMH neurons expressing the NMDA receptor 1 (NR1) subunit, but not those expressing the glutamate receptor 2 and 3 subunits of the AMPA receptors. To confirm this pharmacologically, we tested another group of rats implanted with $\mathrm{L}-\mathrm{AG}$ pumps with intravenous lactate infusions preceded by injections of either NMDA [aminophosphonopentanoic acid (AP-5) or (+)-5-methyl-10,11-dihydro- ${ }^{5} \mathrm{H}$-dibenzo [a,d]cyclohepten-5,10-imine maleate (MK-801)] or non-NMDA [CNQX or 4-(8-methyl- ${ }^{9} \mathrm{H}$-1,3-dioxolo[4,5-h][2,3] benzodazepin-5-yl)-benzenamine dihydrochloride (GYKI52466)] antagonists into the DMH. Injections of NMDA, but not non-NMDA, antagonists into the DMH resulted in dose-dependent blockade of the tachycardia, tachypnea, hypertension, and SI responses after lactate infusions. These results suggest that NMDA, and not non-NMDA, type glutamate receptors regulate lactate-induced panic-like responses in rats with GABA dysfunction in the DMH.
\end{abstract}

Key words: anxiety; subfornical; glutamate decarboxylase; circumventricular; hypothalamus; glutamate; GABA; GAD; immunoreactivity; hypotension; lactate; panic

\section{Introduction}

Panic disorder is a severe anxiety disorder characterized by recurrent panic attacks, affects $\sim 1-2 \%$ of the population, and results in significant morbidity and mortality (Weissman and Merikangas, 1986; Kessler et al., 1994; Hirschfeld, 1996; Katon et al., 2002). Subjects with panic disorder are hypothesized to have disrupted regulation of autonomic and respiratory pathways (Klein, 1993). Consistent with this, subjects with panic disorder are susceptible to panic-like responses after chemical stimuli such as sodium lactate (Liebowitz et al., 1984), $\mathrm{CO}_{2}$ inhalation (Gorman et al., 1994), or yohimbine (Charney et al., 1984) challenges.

A number of limbic and autonomic regulatory centers have been implicated in the pathophysiology of panic disorder and lactate sensitivity (Gorman et al., 2000; Shekhar et al., 2003). The dorsomedial hypothalamus (DMH) is one such site that coordinates neuroendocrine, autonomic, and behavioral responses for a

Received Jan. 28, 2006; revised May 8, 2006; accepted May 29, 2006.

This work was supported by United States Public Health Service Grants R01 MH065702 and MH52619 to A.S. We are grateful to Stanley Keim and Amy D. Dietrich for technical assistance and to William Truitt for technical expertise.

Correspondence should be addressed to Dr. Anantha Shekhar, Indiana University School of Medicine, 1111 West 10th Street, Indianapolis, IN 46202. E-mail: ashekhar@IUPUl.edu.

DOI:10.1523/JNEUROSCI.0408-06.2006

Copyright $\odot 2006$ Society for Neuroscience $\quad$ 0270-6474/06/267093-12\$15.00/0 variety of homeostatic mechanisms (Bernardis and Bellinger, 1998; DiMicco et al., 2002; Chou et al., 2003). Blocking GABA neurotransmission in the DMH of rats elicits panic-like responses such as increases in heart rate (HR), respiratory rate (RR), mean arterial blood pressure (MAP), and experimental anxiety (DiMicco et al., 1986; DiMicco and Abshire, 1987; Shekhar, 1993). Thus the DMH could be an important anatomical substrate in the "panic circuit" (Shekhar, 1994; Shekhar and Katner, 1995). In support of this hypothesis, rats with chronic infusions of the GABA synthesis inhibitor L-allylglycine (L-AG) into the DMH through minipumps show physiological responses to lactate infusions similar to those in panic disorder patients (Shekhar et al., 1996; Shekhar and Keim, 1997).

There appears to be a balance between tonic GABAergic inhibition and glutamate-mediated excitation within the DMH that regulates lactate responses (Shekhar and Keim, 2000). Under basal conditions the activity of DMH neurons is regulated by a tonic GABAergic inhibition of excitatory glutamatergic (both non-NMDA and NMDA) drive (Soltis and DiMicco, 1991). However, when the GABAergic inhibitory tone is reduced with L-AG infusions, the glutamate-mediated excitation appears to become prominent, leading to chronic activation and a panicprone state, because reduction of glutamate release by a presyn- 
aptic agonist of the metabotropic glutamate autoreceptors reverses this effect (Shekhar and Keim, 2000).

The purpose of this study was to investigate the postsynaptic receptor mechanisms of enhanced glutamatergic excitation after chronic disruption of GABA synthesis in the DMH that results in lactate-induced panic-like responses. So that we could determine what role NMDA and AMPA receptors in the DMH play in this panic model, rats received unilateral infusions of L-AG or its inactive isomer $\mathrm{D}-\mathrm{AG}(3.5 \mathrm{nmol} / 0.5 \mu \mathrm{l}$ per hour $)$ into the $\mathrm{DMH}$ for $4-5 \mathrm{~d}$; they received intravenous infusions of $0.5 \mathrm{M}$ sodium lactate (Lac) or saline (Sal) and were fixed with $4 \%$ paraformaldehyde. Double immunocytochemistry was used to assess cellular responses (as measured by the presence of c-Fos, the protein product of the immediate early gene $c$-fos) in DMH neurons expressing either NMDA or AMPA receptor subunits. The NMDA receptor (NR) is made up of the NR1 and NR2 subunits, whereas the AMPA receptor is made up of glutamate receptor 1-4 (GluR1-4) subunits. Antibodies that recognize the NR1 subunit of the NMDA receptor and the GluR2 and 3 subunits of the AMPA receptor were used. We selected these antibodies because the NR1 protein (Petralia et al., 1994) and mRNA (Eyigor et al., 2001) and the GluR2 and 3 proteins (Petralia et al., 1996) and mRNA (Eyigor et al., 2001) expressions are most ubiquitous in the DMH and are equal to or greater than NR2 and GluR1 and 4 subunits. In another group of rats, which received L-AG infusions into the $\mathrm{DMH}$ and were responsive to intravenous sodium lactate infusions, the lactate responses were retested after acute injection of NMDA and non-NMDA antagonists into the DMH.

\section{Materials and Methods}

\section{General procedures}

Animals and housing conditions. All experiments were conducted on adult male Sprague Dawley rats (300-350 g), which were purchased from Harlan Laboratories (Indianapolis, IN) and were housed individually in plastic cages under standard environmental conditions ( $72 \mathrm{~F}^{\circ} ; 12 \mathrm{~h} \mathrm{light/}$ dark cycle; lights on at 7:00 A.M.) for 7-10 d before the surgical manipulations. Food and water were provided ad libitum. Animal care procedures were conducted in accordance with the National Institutes of Health (NIH) Guidelines for the Care and Use of Laboratory Animals (NIH publication 80-23, revised in 1996) and the guidelines of the Indiana University-Purdue University Indianapolis Institutional Animal Care and Use Committee.

Surgical procedures and osmotic minipump infusions. Before surgery the rats were anesthetized with isoflurane after removing them from their home cages and placing them in a closed Plexiglas box that was connected to an isoflurane system (MGX Research Machine; Vetamic, Rossville, IN) and then with a nose cone connected to the same system during the surgery. All rats were fit with femoral arterial catheters for measurement of HR and MAP and with venous catheters for intravenous infusions, as previously described (Shekhar, 1993). After $3 \mathrm{~d}$ of recovery the animals were tested for baseline physiological and behavioral responses to lactate (see below). Each rat then was anesthetized as previously indicated before the implantation of a 28 gauge cannula attached to a T-shaped Alzet osmotic minipump (catalog \#3260PG, 26 gauge; Durect, Cupertino, CA) as described previously (Shekhar et al., 1996). Briefly, cannulas were directed at cardioexcitatory regions of the DMH (Samuels et al., 2004) based on the following coordinates from bregma: $1.2 \mathrm{~mm}$ posterior, +0.5 $\mathrm{mm}$ lateral, $+8.5 \mathrm{~mm}$ ventral, and adjusted for approaching at a $+10^{\circ}$ angle toward the midline, with the stereotaxic incisor bar elevated $5 \mathrm{~mm}$ above the interaural line. A T-shaped pump cannula with a side arm attached to a small Tygon tube was used for pump implantations. Once the cannula was placed at the coordinates targeting the $\mathrm{DMH}, 50 \mathrm{pmol} /$ $100 \mathrm{nl}$ of the $\mathrm{GABA}_{\mathrm{A}}$ receptor antagonist bicuculline methiodide (BMI) was injected through the vertical arm of the cannula via an injection cannula to ascertain that the tip of the pump cannula was placed in a cardioexcitatory region (i.e., where BMI elicits $\geq 50$ beats/min in HR).
Once the reactive site was found, the vertical arm of the cannula was closed by using a stylette, and the side tubing was connected to the metal connector in the minipump that was filled previously with the desired infusion fluid of either the inactive D- or the active L- isomer of allylglycine (D- or L-AG, respectively), an inhibitor of GABA synthesis, in experiment 1 or L-AG only in experiment 2 . Then the pump was sutured under the skin in the nape of the neck, and the connector and cannula were cemented to the skull as described previously (Shekhar et al., 1996). The concentration of the AG solutions was such that $3.5 \mathrm{nmol} / 0.5 \mu \mathrm{l}$ per hour of the drug was infused into the $\mathrm{DMH}$ region over a $5 \mathrm{~d}$ period before intravenous infusions of sodium lactate or physiological saline.

Description of sodium lactate infusion. At 4 or $5 \mathrm{~d}$ after stereotaxic surgery the HR, RR, and MAP were recorded 5 min before infusions (baseline) and for $15 \mathrm{~min}$ during the infusions. The lactate infusion procedure has been described previously (Shekhar et al., 1996). Briefly, freely moving rats in home cages were given intravenous infusions of either $0.9 \%$ saline vehicle or $0.5 \mathrm{M}$ sodium lactate in vehicle $(10 \mathrm{ml} / \mathrm{kg}$ over $15 \mathrm{~min}$ ), similar to clinical lactate infusions (Liebowitz et al., 1986). Cardiovascular responses that were reported are the maximum change in $\mathrm{HR}$ (in beats/min), RR (in breaths/min), and MAP (in $\mathrm{mmHg}$ ) for each animal.

Social interaction test. The social interaction (SI) test is a fully validated test of experimental anxiety-like behavior in rats (File, 1980), and the procedure as used in our laboratory has been described previously (Sanders et al., 1995; Shekhar and Katner, 1995). The apparatus itself consists of a solid wooden box with an open roof $\sim 0.9 \mathrm{~m}$ long $\times 0.9 \mathrm{~m}$ wide with walls $0.3 \mathrm{~m}$ high. A video camera was fixed above the box, and all behavioral tests were videotaped. A day before SI tests the "experimental" rat and an unfamiliar "partner" rat were placed individually in the center of the box and allowed to habituate to the environment for a 5 min period. During the SI test the two rats were placed together in the center of the box, and the number of seconds of nonaggressive physical contact (grooming, sniffing, crawling over and under, etc.) initiated by the experimental rat was counted. A baseline SI test was performed $\sim 72 \mathrm{~h}$ after intravenous catheterization but before osmotic minipump implantation. Another SI test was performed 6-8 d after infusions of either D-AG or $\mathrm{L}-\mathrm{AG}$ into the DMH region through osmotic minipumps and immediately after intravenous infusions of either saline or sodium lactate. Sessions were scored at a later time by two raters, of whom at least one was blind to any drug treatment.

\section{Experimental procedures}

Experiment 1. Lactate response in panic-prone and control rats for doublelabeling glutamate receptor and c-Fos in the DMH. At $5 \mathrm{~d}$ after stereotaxic surgery the rats $(n=24)$ implanted with either L-AG or D-AG pumps in the DMH ( $n=12$ each) were assigned randomly to lactate or saline groups and were given their assigned intravenous infusion (saline or sodium lactate; $n=12$ each); the changes in HR and MAP were recorded 5 min before infusions (baseline) and 15 min during the infusions. After the infusions, the animals were perfused, and their brains were removed and processed for immunocytochemistry as described in immunocytochemistry methods below.

Experiment 2. Effects of glutamate receptor antagonists in the DMH on lactate responses in panic-prone rats. First the rats $(n=6$ each) with L-AG pumps implanted in the DMH were confirmed to be "anxious" in the SI test and reactive to lactate infusions by postoperative day 4 . On day 6 the stylette from the vertical arm of the pump cannula of these rats was removed, an injection cannula was inserted into the guide, and they were given an acute $100 \mathrm{nl}$ injection of one of the following drug solutions: artificial CSF (vehicle), the selective competitive NMDA antagonist D,Laminophosphonopentanoic acid (D,L-AP-5; 1, 10, or 100 pmol) or its inactive isomer L-AP-5 (100 pmol), the selective noncompetitive NMDA antagonist dizocilpine maleate, (+)-5-methyl-10,11-dihydro- ${ }^{5} \mathrm{H}$ dibenzo [a,d]cyclohepten-5,10-imine maleate (MK-801; 25 or 125 pmol), the selective competitive AMPA antagonist CNQX (50, 250, or $500 \mathrm{pmol})$, or the selective noncompetitive AMPA antagonist 4-(8methyl- ${ }^{9} \mathrm{H}$-1,3-dioxolo[4,5-h] [2,3] benzodazepin-5-yl)-benzenamine dihydrochloride (GYKI52466; 250 or 500 pmol) in a counterbalanced order into the DMH and tested again with lactate infusions. On day 8 a 
similar procedure was repeated, but this time the acute injection into the $\mathrm{DMH}$ was the remaining (artificial CSF or glutamate antagonists) drug. At the end of the experiments the rats were killed, and the brains were sectioned for histological examination of injection/infusion sites.

\section{Immunocytochemical methods for experiment 1}

Perfusion. At 90 min after the last sodium lactate infusion (i.e., in rats with post-L-AG or D-AG pump infusions), the rats were anesthetized with an overdose of sodium pentobarbital $(40 \mathrm{mg} / \mathrm{kg}$, i.p. $)$ and then perfused transcardially with $0.05 \mathrm{M}$ PBS $(250 \mathrm{ml})$, followed by $0.1 \mathrm{M}$ sodium phosphate buffer $(\mathrm{PB} ; 250 \mathrm{ml})$ containing $4 \%$ paraformaldehyde and $3 \%$ sucrose. Brains were removed and postfixed for $24 \mathrm{~h}$ in the same fixative, rinsed for $24 \mathrm{~h}$ in $0.1 \mathrm{M} \mathrm{PB}$, and then placed in cryoprotectant ( $30 \%$ sucrose in $0.1 \mathrm{M} \mathrm{PB}$ ) for an additional $4-5 \mathrm{~d}$. To maintain a consistent plane for coronal sections, we placed the brains in a rat brain matrix (model RBM-4000C; ASI Instruments, Warren, MI) and cut them with a razor blade at approximately $-5.20 \mathrm{~mm}$ bregma (at the caudal border of the mamillary bodies). Brains were frozen in cooled liquid isopentane made by immersing a plastic vessel containing isopentane into a container filled with dry ice. Serial coronal sections $(30 \mu \mathrm{m})$ were cut with a cryostat and then were placed immediately in cryoprotectant consisting of $27 \%$ ethylene glycol and $16 \%$ glycerol in $0.05 \mathrm{M}$ PB to yield six alternate sets of sections (three of the six alternative sets of sections were stained for methyl green, c-Fos/NR1, and c-Fos/GluR2/3). Sections were stored at $-20^{\circ} \mathrm{C}$ until immunohistochemical processing. All solutions had a pH of 7.4.

Minipump cannula placement verification. One series of coronal sections was mounted on slides, dried overnight, hydrated, stained with $1 \%$ methyl green solution in $\mathrm{H}_{2} \mathrm{O}$ (catalog \#198080; Sigma, Poole, UK), dehydrated, and mounted with coverslips with the use of DPX mounting medium (BDH Laboratory Supplies, Poole, UK). Minipump cannula tip placement was verified at $400 \times$ magnification via a Leica DME binocular microscope (Fisher Scientific, Leicestershire, UK) by an investigator (P.L.J.) who was blind to the experimental treatment of the animals.

GABA immunohistochemistry. One series of hypothalamic brain sections was immunostained for GABA, which was accomplished by using primary antibodies directed at GABA (rabbit anti-GABA polyclonal affinity-purified antibody, catalog \#2052; Sigma) (diluted 1:15,000). For GABA immunostaining the free-floating sections were washed in $0.05 \mathrm{M}$ PBS for $30 \mathrm{~min}$ and then incubated in $1 \% \mathrm{H}_{2} \mathrm{O}_{2}$ in PBS for $20 \mathrm{~min}$. Sections then were washed for $10 \mathrm{~min}$ in PBS and for $20 \mathrm{~min}$ in PBS with $0.3 \%$ Triton X-100 (PBST). Sections next were incubated for $14-16 \mathrm{~h}$ in PBST with primary antibody solution at room temperature. After a 30 min wash in PBST the sections were incubated for $2 \mathrm{~h}$ in a biotinylated swine anti-rabbit IgG secondary antibody (GABA, catalog \#E0353; DAKO, Cambridgeshire, UK) (diluted 1:500). Sections were washed again for $30 \mathrm{~min}$ in PBST and then were incubated for $1.5 \mathrm{~h}$ in an avidinbiotin complex (catalog \#PK-6100; Vector Laboratories, Burlingame, CA) (diluted 1:500). Substrate for chromogen reaction was $0.01 \% 3,3^{\prime}$ diaminobenzidine tetrahydrochloride (DAB; catalog \#D-5637; Sigma) in $\mathrm{PB}$ containing $0.003 \% \mathrm{H}_{2} \mathrm{O}_{2}$ and a $2 \%$ nickel sulfate solution. Substrate reactions were run for $10 \mathrm{~min}$ for GABA. All sections were mounted on clean glass slides, dried overnight, dehydrated, and mounted with coverslips with the use of DPX mounting medium (BDH Laboratory Supplies). All washes and incubations were done in 24-well polystyrene plates with low-frequency shaking on an orbital shaker.

Double immunohistochemistry. Two series of hypothalamic brain sections were double immunostained sequentially for c-Fos protein first and either NR1 or GluR2/3 afterward. Double immunostaining for c-Fos protein and either NR1 or GluR2/3 protein was accomplished by using primary antibodies directed against c-Fos (rabbit anti-c-Fos-polyclonal affinity-purified antibody, catalog \#PC38, Ab-5; Calbiochem, La Jolla, CA) (diluted 1:10,000) and either NR1 (goat anti-NR1-polyclonal, affinity-purified IgG antibody with epitope mapping at the $\mathrm{C}$ terminus of NMDA $\zeta 1$ of human origin; catalog \#sc1467; Santa Cruz Biotechnology, Santa Cruz, CA) (diluted 1:500) or GluR2/3 (rabbit anti-GluR2 with an epitope mapping at the $\mathrm{C}$ terminus peptide of the GluR2 of rat origin that recognizes both GluR2 and GluR3, which have nearly identical C-terminal sequences; catalog \#AB1506; Chemicon, Temecula, CA) (di- luted 1:300). Free-floating sections were washed in $0.05 \mathrm{M}$ PBS for $30 \mathrm{~min}$ and then incubated in $1 \% \mathrm{H}_{2} \mathrm{O}_{2}$ in PBS for 20 min. Sections next were washed for $10 \mathrm{~min}$ in PBS and for $20 \mathrm{~min}$ in PBS with $0.3 \%$ Triton X-100 (PBST). Then the sections were incubated for $12-16 \mathrm{~h}$ in PBST with primary antibody solution at room temperature. After a $30 \mathrm{~min}$ wash in PBST the sections were incubated for $2 \mathrm{~h}$ in the appropriate secondary antibody [(c-Fos, GluR2/3: biotinylated swine anti-rabbit IgG, catalog \#E0353; Dako, Carpinteria, CA) (diluted 1:500) (NR1: biotinylated rabbit anti-goat IgG, catalog \#BA5000; Vector Laboratories) (diluted 1:500)]. Sections were washed again for $30 \mathrm{~min}$ in PBST and then incubated for $1.5 \mathrm{~h}$ in an avidin-biotin complex (catalog \#PK-6100; Vector Laboratories) (diluted 1:500). Substrates for chromogen reactions were Vector SG (c-Fos, catalog \#SK-4700; Vector Laboratories) or 0.01\% DAB (NR1 and GluR2/3, catalog \#D-5637; Sigma, St. Louis, MO) in PBS containing $0.003 \% \mathrm{H}_{2} \mathrm{O}_{2}, \mathrm{pH}$ 7.4. Substrate reactions were run for $20 \mathrm{~min}$ for c-Fos and NR1 or GluR2/3. All sections were mounted on clean glass slides, dried overnight, dehydrated, and mounted with coverslips with the use of DPX mounting medium (catalog \#13512; Electron Microscopy Sciences, Ft. Washington, PA). All washes and incubations were done in 24-well polystyrene plates with low-frequency shaking on an orbital shaker.

Data processing for immunocytochemistry. Image analysis of GABA immunohistochemistry was done in the DMH and in the lateral hypothalamus (LH; at approximately $-3.14 \mathrm{~mm}$ bregma) ipsilateral and contralateral to the D-AG or L-AG infusions. Image analysis was done by using the IMAGE J software (version 1.33) developed by Wayne Rasband from the NIH (publicly available at http://rsb.info.nih.gov/ij/) on highresolution photographs $(25 \times$ magnification $)$ of hypothalamic brain sections immunostained for GABA. Photographs of GABA immunostaining were taken by using the same exposure and were saved as eight-bit gray scale images. A square area was selected $\left(0.25 \mathrm{~mm}^{2}\right)$ in the DMH immediately lateral to the top of the third ventricle, and the mean gray scale value was calculated from a histogram of the photograph from each rat. The same was done for the $\mathrm{LH}$, in which a square area $\left(0.25 \mathrm{~mm}^{2}\right)$ was selected lateral to the fornix. Each dependent variable (gray scale value of GABA immunocytochemistry) was analyzed by using a two-way ANOVA, with lactate and isomer as main factors and side (ipsilateral vs contralateral) as repeated measures.

Cell counts for c-Fos were done at $400 \times$ magnification on a $0.85 \mathrm{~mm}^{2}$ area/side (i.e., ipsilateral and contralateral) (see Fig. $1 A$ ) with a Leica DME binocular microscope (Leica Microsystems, Nussloch, Germany) by an investigator (P.L.J.) who was blind to the experimental treatment of each animal. To count c-Fos-positive NR1 and GluR2/3-immunoreactive (GluR2/3-IR) cells and to control for area, we centered a $20 \times$ objective (200× magnification) on the farthest point of the field of view away from the third ventricle at $-3.14 \mathrm{~mm}$ bregma. Then the objective was changed to the 40 objective ( $400 \times$ magnification). All c-Fos/NR1 or c-Fos/GluR2/3-IR cells were counted from this point and scanned medially to the third ventricle (representing a $0.85 \mathrm{~mm}^{2}$ area) (see Fig. $1 \mathrm{~A}$ ). The area of the DMH that was counted was approximately square in dimension, with the corners being the mamillothalamic tract, the fornix, the top of the third ventricle, and halfway down the third ventricle (immediately medial from the fornix). This area then was divided into dorsal and ventral halves. The $\mathrm{DMH}$, as described, is particularly sensitive to BMI-induced cardioexcitatory response (Samuels et al., 2004), receives projections from circumventricular organs (CVOs) such as the organum vasculosum lamina terminalis (OVLT) (Thompson and Swanson, 1998), and has selective neurochemical changes that follow stress (Lowry et al., 2003). The single c-Fos-immunoreactive (c-Fos-IR) and c-Fos/NR1 or c-Fos/GluR2/3-IR cell counts were done in the dorsal DMH region [i.e., mainly made up of the dorsal hypothalamic area (DA) but also including part of the subincertal region (SubI)] and ventral DMH region [i.e., mainly made up of the dorsal part of the dorsomedial hypothalamic nucleus (DMD) but also including part of the perifornical region $(\mathrm{PeF})$ ] at $-3.14 \mathrm{~mm}$ bregma. Because of the high numbers of NR1-IR cells in the $\mathrm{DMH}$, high-resolution photomicrographs were taken at $200 \times$ magnification (representing $0.7 \mathrm{~mm}^{2}$ area/side for the DA/SubI and PeF/DMD) and placed in a graphic illustration program (CorelDRAW Photoshop 11.633 for Windows; Viglen, Alperton, Middlesex, UK); a dot was placed 
over each NR1 or GluR2/3-IR nucleus to prevent overcounting or undercounting.

Photography. Photomicrographs were obtained via a Leica bright-field microscope, using N-plan $5 \times, 10 \times, 20 \times$, and $40 \times$ objective lenses (model DMLB; Leica Microsystems), a SPOT digital camera (Diagnostic Instruments, Sterling Heights, MI), and SPOT 4.0.6 for Windows digitalimaging software (Silicon Graphics, Mountain View, CA). Photographic plates were prepared in CorelDRAW 11.633 for Windows (Eden Prairie, $\mathrm{MN})$.

Statistical analyses. Each dependent variable for in vivo analyses (i.e., SI duration, HR, and MAP) was analyzed by using a two-way ANOVA with repeated measures, with lactate and isomer as main factors and time as repeated measures. Each dependent variable for cell counts (c-Fos, c-Fos/ NR1, NR1, c-Fos/GluR2/3, and GluR2/3-IR cells) was analyzed by using a two-way ANOVA, with lactate and isomer as main factors. Levene's Test of Equality of Error Variance also was done to determine equal variances in the groups. In the instance that there were equal variances in the groups and in the presence of significant main effects, post hoc tests were conducted by using a parametric Tukey's test. In the instance that there were unequal variances in the groups, post hoc tests were conducted by using a nonparametric Kruskal-Wallis test. A two-tailed Pearson's Product Moment was used for all correlations. Statistical significance was accepted with $p<0.05$. All statistical analyses were performed by using SPSS 13.0 (SPSS Science, Chicago, IL) and SYSTAT 5.02 for Windows (Systat, Evanston, IL), and all graphs were generated by using SigmaPlot 2001 for Windows (SPSS Science).

\section{Results}

Experiment 1. Glutamate receptor and c-Fos double labeling in panic-prone and control rats Osmotic minipump probe placement

All minipump cannula placements resided in regions of the $\mathrm{DMH}$ and posterior hypothalamus $(\mathrm{PH})$ known to be cardioexcitatory (Fig. 1 A) (Shekhar and Keim, 1997; Samuels et al., 2004) and were verified physiologically by injecting BMI under anesthesia and obtaining increases in HR (i.e., in which BMI elicited $\geq 50$ beats/min in HR). Although there was some tissue damage at the site of implantation, this damage was minimal and was observed equally in the control and experimental groups, with the majority of cells in the DMH/PH still intact surrounding the infusion site and stained with methyl green (data not shown).

\section{Anxiety-like behavior}

A Levene's test revealed equal variance among groups $\left(F_{(3,18)}=\right.$ $6.2 ; p=0.613)$. Previous L-AG infusions into the DMH/PH region decreased the amount of time in SI test when compared with prepump baseline and with $\mathrm{D}-\mathrm{AG}$ controls. [There was an isomer effect $\left(F_{(1,18)}=71.5 ; p<0.001\right)$ and a lactate times isomer interaction $\left(F_{(1,18)}=9.7 ; p<0.01\right)$, but no lactate effect $\left(F_{(1,18)}=0.6\right.$; $p=0.445$ ) (data not shown).] Post hoc analyses revealed that the L-AG decreased the duration of SI time independently of either saline or sodium lactate infusions. There were no significant differences in baseline SI time among treatment groups before either D-AG or L-AG infusions.

\section{Cardiovascular physiology}

Intravenous infusions of sodium lactate elicited increases in MAP (Fig. $1 B$ ) [between subjects results: there were no isomer $\left(F_{(1,14)}=0.25 ; p=0.62\right)$ or lactate effects $\left(F_{(1,14)}=0.001 ; p=\right.$ $0.97)$, but there was a lactate times isomer interaction $\left(F_{(1,14)}=\right.$ 5.2; $p<0.05)$; within subjects results: there was no isomer times time interaction $\left(F_{(1,14)}=2.3 ; p=0.153\right)$, but there was a lactate times time $\left(F_{(1,14)}=10.6 ; p<0.01\right.$ and a lactate times isomer times time interaction $\left.\left(F_{(1,14)}=6.9 ; p<0.03\right)\right]$ and $\mathrm{HR}($ Fig. $1 C)$ [between subjects results: there were no isomer $\left(F_{(1,15)}=3.6 ; p=\right.$ $0.079)$ or lactate $\left(F_{(1,15)}=1.1 ; p=0.319\right)$ effects, but there was a
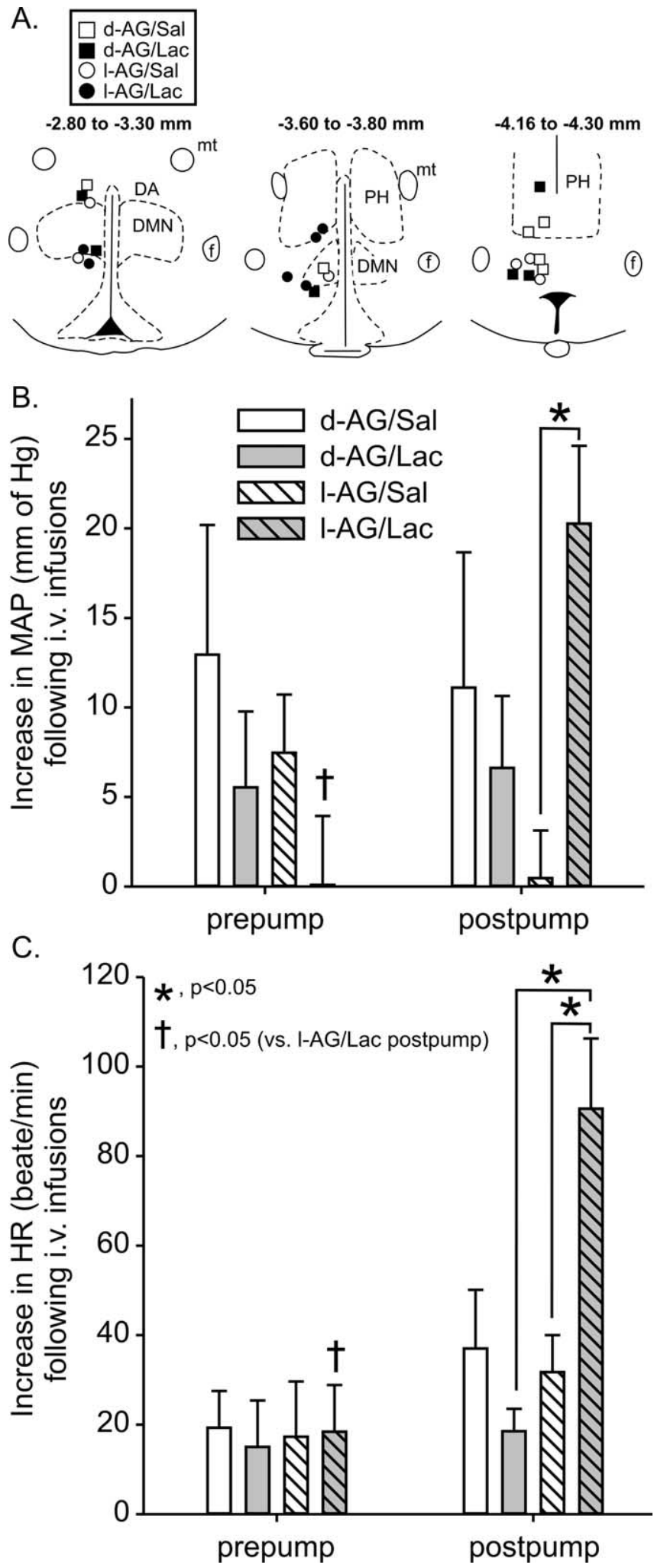

Figure 1. The effect of intravenous sodium lactate infusions on cardiovascular physiology in rats made panic-prone with previous GABA inhibition in the DMH region. $\boldsymbol{A}$, Distribution of osmotic minipump placements in the DMH/PH from experiment 1. Shown are illustrations of probe placements from -2.80 to $-3.30 \mathrm{~mm}$ bregma, from -3.60 to $-3.80 \mathrm{~mm}$ bregma, and from -4.16 to $-4.30 \mathrm{~mm}$ bregma. The treatment associated with each cannula placement is represented by symbols (square or circle) with shading (white or black). B, C, Also shown are the effects of sodium lactate infusions on the change in the MAP $(\boldsymbol{B})$ and $H R(\boldsymbol{C})$ before and after infusions of either L-AG (a GABA synthesis inhibitor) or its inactive isomer D-AG in the DMH. Values of the bars represent the mean; the error bars represent the SEM. ${ }^{*}{ }^{+} p<0.05$. 
lactate times isomer interaction $\left(F_{(1,15)}=5.2 ; p<0.04\right)$; within subjects results: there was no lactate times time interaction $\left(F_{(1,15)}=2.6 ; p=0.128\right)$, but there was an isomer times time interaction $\left(F_{(1,15)}=5.9 ; p<0.03\right)$ and a lactate times isomer times time interaction $\left.\left(F_{(1,15)}=7.11 ; p<0.02\right)\right]$ only in those rats previously receiving previous $\mathrm{L}-\mathrm{AG}$ infusions into the $\mathrm{DMH} / \mathrm{PH}$ region. There was also equal variance in all groups (prepump MAP, Levene's $F_{(3,14)}=0.58 ; p=0.640$; postpump MAP, Levene's $F_{(3,14)}=0.39 ; p=0.761$; prepump HR, Levene's $F_{(3,14)}=$ $0.56 ; p=0.649$ ) except postpump HR (Levene's $F_{(3,14)}=4.15$; $p=0.025)$. As predicted, there was no physiological arousal to the lactate infusions in the control rats that received D-AG infusions into the $\mathrm{DMH} / \mathrm{PH}$ region or before either $\mathrm{L}-\mathrm{AG}$ or $\mathrm{D}-\mathrm{AG}$ minipump infusions (Fig. $1 \mathrm{~B}, \mathrm{C}$ ). Post hoc analysis revealed that sodium lactate infusions increased HR and MAP only in L-AG rats and that the increase in MAP and HR occurred between 6 and $8 \mathrm{~min}$ after intravenous infusions, respectively. The mean baseline values for each treatment group were $124 \pm 4$ SEM, $135 \pm 20$ SEM, $123 \pm 1$ SEM, and $110 \pm 5$ SEM $\mathrm{mmHg}$ for MAP and $408 \pm$ 34 SEM, $415 \pm 8$ SEM, $398 \pm 22$ SEM, and $374 \pm 11$ SEM BPM for HR for D-AG/Sal, D-AG/Lac, L-AG/Sal, and L-AG/Lac, respectively. There was also equal variance in all groups for MAP (Levene's $F_{(3,14)}=2.5 ; p=0.101$ ) and HR (Levene's $F_{(3,15)}=0.5 ; p=$ $0.655)$, and these values did not differ between treatment groups when we used a two-way ANOVA [MAP: isomer $\left(F_{(1,14)}=1.0\right.$; $p=0.324)$, lactate $\left(F_{(1,14)}=0.01 ; p=0.915\right)$, isomer times lactate $\left(F_{(1,14)}=0.8 ; p=0.380\right)$; HR: isomer $\left(F_{(1,15)}=1.5 ; p=0.228\right)$, lactate $\left(F_{(1,15)}=0.2 ; p=0.667\right)$, isomer times lactate $\left(F_{(1,15)}=\right.$ $0.6 ; p=0.446)]$.

\section{GABA immunostaining in the DMH and $L H$}

Image analysis of photographs of GABA immunostaining in the $\mathrm{DMH}$ revealed that infusion of $\mathrm{L}-\mathrm{AG}$, but not $\mathrm{D}-\mathrm{AG}$, into the $\mathrm{DMH}$ region decreased the intensity of GABA immunostaining ipsilateral, but not contralateral, to the minipump cannula in the $\mathrm{DMH}$ (Fig. $2 A, B$ ) [between subjects results: there was no isomer $\left(F_{(1,20)}=2.5 ; p=0.128\right)$ or lactate effect $\left(F_{(1,20)}=1.4 ; p=0.255\right)$ or isomer times lactate interaction $\left(F_{(1,20)}=0.1 ; p=0.738\right)$; within subjects results: there was an isomer times side interaction $\left(F_{(1,20)}=13.5 ; p<0.002\right)$, but no lactate times side interaction $\left(F_{(1,20)}=2.1 ; p=0.159\right)$ or isomer times lactate times sidej interaction $\left(F_{(1,20)}=2.4 ; p=0.134\right)$ for mean gray scale value]. There was also equal variance in all groups (ipsilateral, Levene's $F_{(3,20)}=0.7 ; p=0.540$, and contralateral, Levene's $F_{(3,20)}=1.5$; $p=0.248)$.

Although image analysis of photographs of GABA immunostaining in the LH failed to reveal any treatment effect (Fig. 2A) [between subjects results: there was no isomer $\left(F_{(1,20)}=1.4 ; p=\right.$ $0.252)$ or lactate effect $\left(F_{(1,20)}=0.5 ; p=0.475\right)$ or isomer times lactate interaction $\left(F_{(1,20)}=0.2 ; p=0.694\right)$; within subjects results: there was no isomer times side $\left(F_{(1,20)}=4.3 ; p=0.051\right)$, lactate times side $\left(F_{(1,20)}=1.4 ; p=0.242\right)$ or isomer times lactate times side interaction $\left(F_{(1,20)}=0.9 ; p=0.364\right)$ for mean gray scale value], an isomer times side effect approached significance. There was also equal variance in all groups (ipsilateral, Levene's $F_{(3,20)}=1.5 ; p=0.242$, and contralateral, Levene's $F_{(3,20)}=1.1$; $p=0.354)$.

\section{Combined glutamate receptor subunit and} c-Fos immunoreactivity

Sodium lactate infusions increased the mean number of c-Fos/ NR1-IR cells in the DMH ipsilateral [There was equal variance among groups in the DA/SubI (Levene's $F_{(3,20)}=2.7 ; p=0.072$ ), and there was an isomer effect $\left(F_{(1,20)}=5.7 ; p<0.03\right)$ and isomer

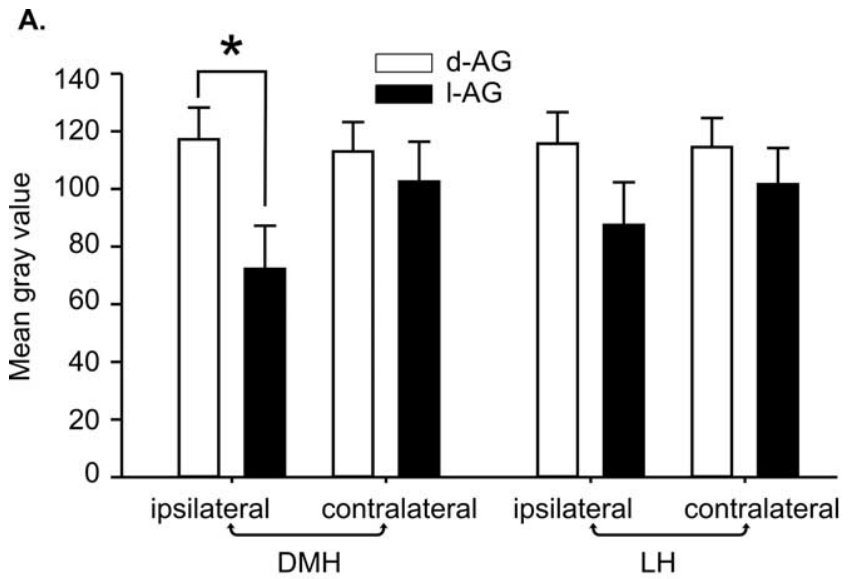

B. d-AG/Sal

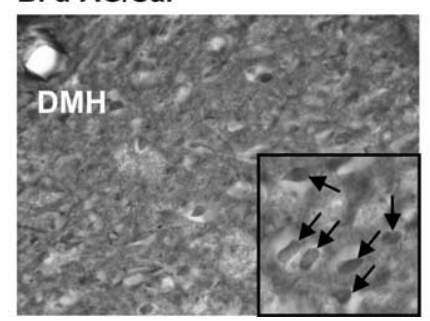

I-AG/Sal

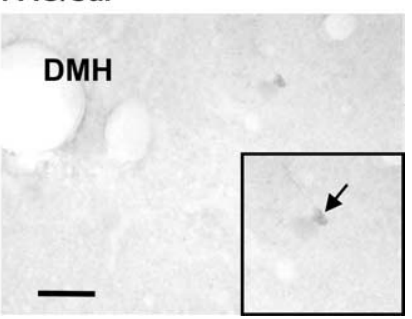

Figure 2. The effect that GABA synthesis inhibition (L-AG) or D-AG controls had on the intensity of GABA immunostaining in the DMH and LH. $A$, Mean brightness of GABA immunostaining ipsilateral and contralateral to minipump cannulas in the DMH and LH. Values of the bars represent the mean gray scale value; error bars represent the SEM $\left.{ }^{*} p<0.002\right)$. $\boldsymbol{B}$, Highmagnification photographs of GABA-IR cells adjacent to the minipump cannula in the DMH in D-AG/Sal-treated (left) and L-AG/Sal-treated (right) rats. Small photographic insets in $\boldsymbol{B}$ are cropped and enlarged images taken from original left and right photographs at higher magnification. Arrows in photographic insets indicate GABA-IR cells. Scale bars: $\boldsymbol{B}, 200 \mu \mathrm{m} ; \boldsymbol{B}$, bottom left inset, $50 \mu \mathrm{m} ; \boldsymbol{B}$, bottom right inset, $20 \mu \mathrm{m}$.

times lactate effect $\left(F_{(1,20)}=5.0 ; p<0.05\right)$, but no lactate effect $\left(F_{(1,20)}=3.0 ; p=0.10\right)$; a Levene's test revealed unequal variance among groups in the PeF/DMD (Levene's $F_{(3,20)}=6.6 ; p<0.01$ ); therefore, nonparametric post hoc tests were used (Fig. $3 C$ ) for these groups.], but not contralateral. [There was equal variance among groups in the DA/SubI (Levene's $F_{(3,20)}=0.3 ; p=0.813$ ), and there was an isomer effect $\left(F_{(1,20)}=5.7 ; p<0.03\right)$ and isomer times lactate interaction $\left(F_{(1,20)}=5.0 ; p<0.05\right)$, but no lactate effect $\left(F_{(1,20)}=3.0 ; p=0.10\right)$; there was equal variance among groups in the PeF/DMD (Levene's $F_{(3,20)}=2.2 ; p=0.108$ ), and there was an isomer effect $\left(F_{(1,20)}=6.5 ; p<0.02\right)$, but no lactate effect $\left(F_{(1,20)}=3.0 ; p=0.10\right)$ or lactate times isomer interaction $\left(F_{(1,20)}=3.0 ; p=0.10\right)$.] to isomer infusions in only those rats receiving previous infusions of $\mathrm{L}-\mathrm{AG}$ into the $\mathrm{DMH} / \mathrm{PH}$ region as compared with D-AG controls (Figs. $3 A, C, 4 A$ ).

Sodium lactate infusions failed to alter the mean number of c-Fos/GluR2/3-IR cells in the DMH ipsilateral [Within the DA/ SubI a Levene's test revealed unequal variance among groups (Levene's $\left.F_{(3,20)}=6.7 ; p<0.01\right)$; therefore, nonparametric post hoc tests were used for these groups. Within the PeF/DMD there was equal variance among groups (Levene's $F_{(3,19)}=1.0 ; p=$ $0.408)$, but there was no isomer $\left(F_{(1,19)}=1.1 ; p=0.309\right)$ or lactate effect $\left(F_{(1,20)}=0.2 ; p=0.689\right)$ or isomer times lactate interaction $\left(F_{(1,20)}=0.2 ; p=0.689\right)$.] or contralateral [Within the DA/SubI a Levene's test revealed unequal variance among groups (Levene's $\left.F_{(3,20)}=10.0 ; p<0.001\right)$; therefore, nonparametric post hoc tests were used for these groups. Within the PeF/ DMD there was equal variance among groups (Levene's $F_{(3,18)}=$ 
A.

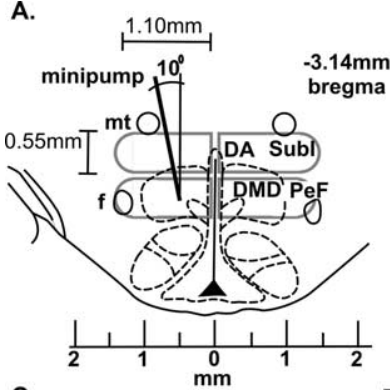

B.

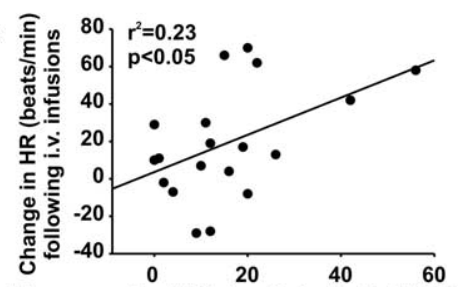

Mean no. c-Fos/NR1-ir cells in the PeF/DMD (ipsilateral to $d-A G$ or I-AG infusions)

C.
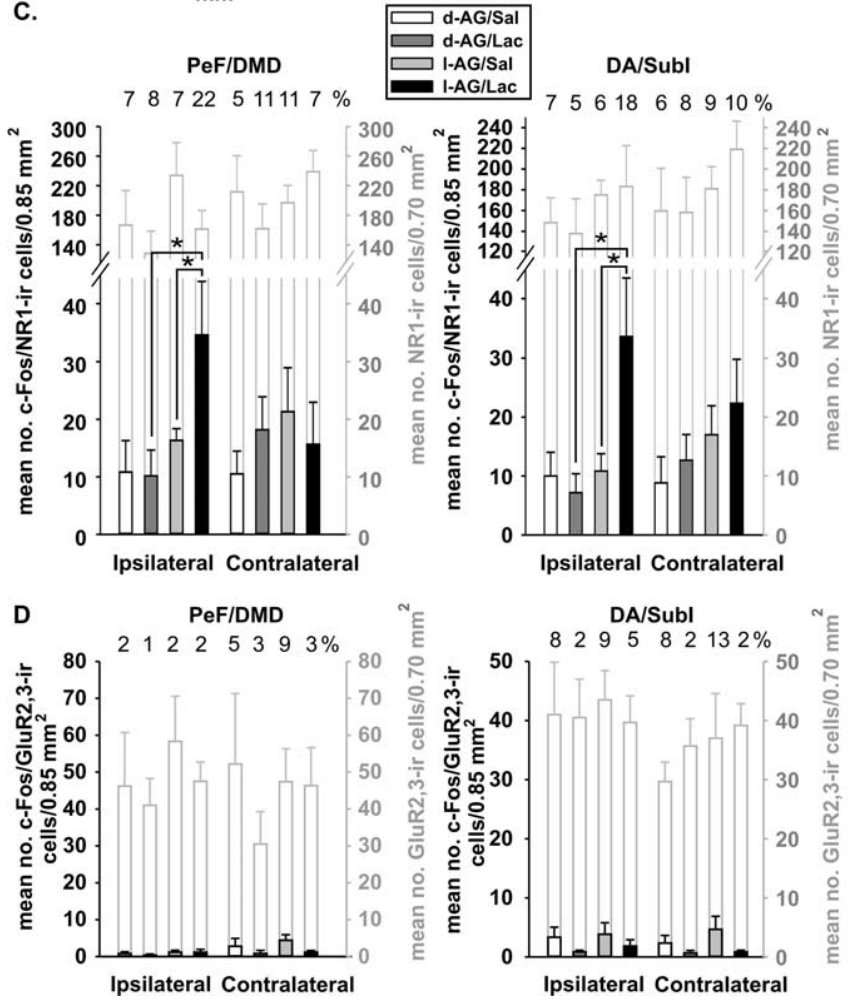

Figure 3. Graphs indicating c-Fos responses in dorsal hypothalamic cells expressing either the NMDA or AMPA receptor subunits (NR1 and Glu2/3 receptor subunits, respectively). $\boldsymbol{A}$, Illustration of the DMH region at $-3.14 \mathrm{~mm}$ bregma adapted from a standard stereotaxic rat brain atlas indicating unilateral minipump placement and gray outlines indicating regions in which numbers of $c-$ Fos/NR1 or $c-F o s / G l u R 2 / 3$ double-IR cells were counted. $\boldsymbol{B}$, The mean number of C-Fos/NR1-IR cells in the PeF/DMD ipsilateral to the D-AG or L-AG infusions correlated with changes in HR from baseline to post-intravenous infusions. C, Graphs indicate number of c-Fos-positive NR1-IR neurons in the DMH region ipsilateral (left) and contralateral (right) to D-AG or L-AG infusions. Bars with black lines equal the number of c-Fos/NR1-IR neurons \pm SEM; open bars with gray lines equal the total number of NR1-IR neurons \pm SEM. Numbers above open gray bars represent the approximate percentage of the total number of NR1-IR neurons that are c-Fos positive. D, Graphs indicate the number of c-Fos-positive GluR2/3-IR neurons in the DMH region ipsilateral (left) and contralateral (right) to D-AG or L-AG infusions. Bars with black lines equal the number of C-Fos/GluR2/3-IR neurons \pm SEM; open bars with gray lines equal the total number of GluR2/3-IR neurons \pm SEM. Numbers above open gray bars represent the approximate percentage of the total number of GluR2/3-IR neurons that are c-Fos positive. ${ }^{*} p<0.05$. f, Fornix; mt, mamillothalamic tract; no., number.

$2.3 ; p=0.111)$, but there was no isomer $\left(F_{(1,18)}=0.5 ; p=0.466\right)$ or lactate $\left(F_{(1,18)}=4.0 ; p=0.061\right)$ effect or isomer times lactate interaction $\left(F_{(1,18)}=0.7 ; p=0.632\right)$.] to isomer infusions only in those rats receiving previous infusions of L-AG into the $\mathrm{DMH} / \mathrm{PH}$ region as compared with D-AG controls (Figs. $3 A, D, 4 B$ ).

The total numbers of NR1 or GluR2/3-IR cells were similar in either the DA/SubI or PeF/DMD (ipsilateral or contralateral) of rats infused with either isomer (Fig. 3C,D). Additional analysis
A: c-Fos/NR1 in DA
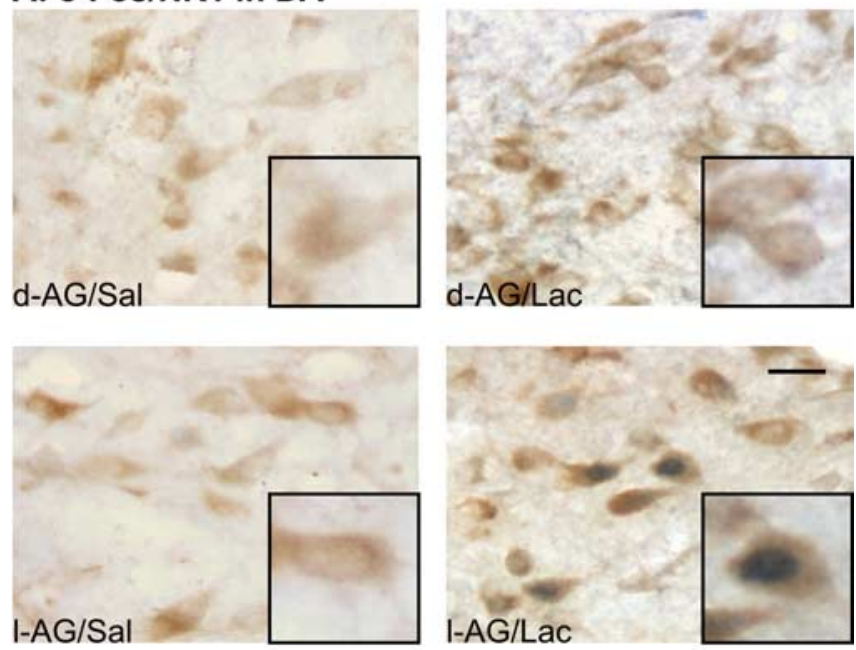

\section{B: c-Fos/GluR2,3 in DA}
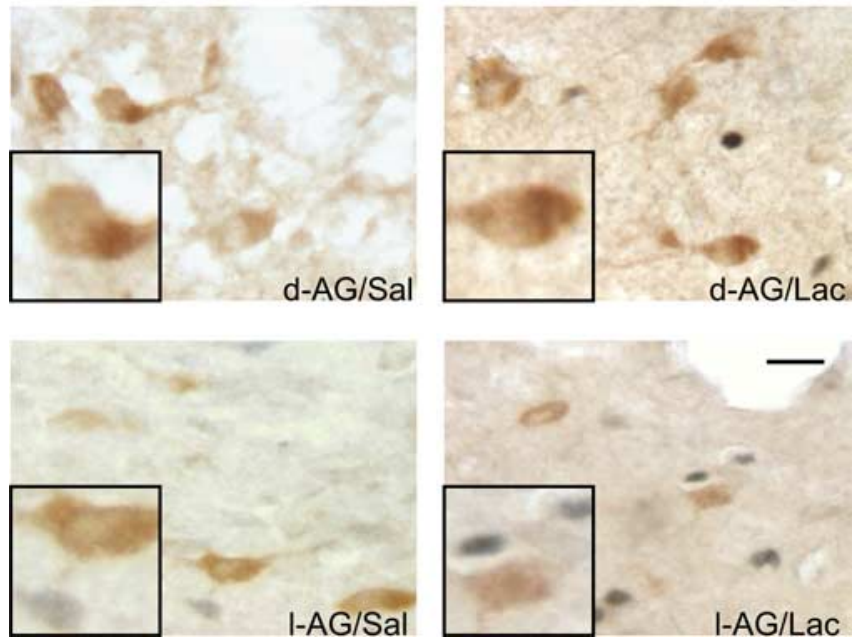

Figure 4. Photographs of cellular responses (i.e., the presence of c-Fos) in either NMDA or AMPA receptor subunit-expressing cells in the DMH region. Photographs show c-Fos-IR nuclear staining (blue) and NR1-IR ( $\boldsymbol{A}$ ) or GluR2/3-IR (B) cytoplasmic staining (brown) in the DA of each treatment group, which is indicated in the bottom corner of each photograph (e.g., D-AG/Sal). Scale bars: low-magnification photographs, $25 \mu \mathrm{m}$; small inset photographs, $12 \mu \mathrm{m}$.

revealed that the number of c-Fos/NR1-IR cells in the PeF/DMD (ipsilateral to minipump infusions) was correlated positively with difference in the mean change of $\operatorname{HR}\left(r^{2}=0.23 ; p<0.05\right)$ (Fig. $3 B)$, but not MAP $\left(r^{2}=0.01 ; p=0.74\right)$ or the duration of SI $\left(r^{2}=0.12 ; p=0.11\right)$ after lactate infusions. No additional correlations were observed among c-Fos/NR1, total NR1, c-Fos/ GluR2/3, or total GluR2/3-IR cells in the DMH with changes in cardiovascular measures from baseline to post-intravenous infusions. A random sample of immunoreactive cells revealed that (1) most NR1-IR cells had an average width of $11 \mu \mathrm{m}$ and length of $24 \mu \mathrm{m}$, whereas GluR2/3-IR cells had an average width of $11 \mu \mathrm{m}$ and length of $20 \mu \mathrm{m}$, and (2) the vast majority of NR1 and GluR2/ 3-IR cells had a morphology consistent with neurons (Fig. 4A, B). Within the DMH (i.e., DA/SubI and PeF/DMD) the numbers of NR1 and GluR2/3-IR neurons were expressed ubiquitously. With the exception of NR1-IR cells in the DMD, there did not appear to be any regional difference in the size and shape of NR1 and GluR2/3-IR cells in the DMH. Within the pars compacta region 
A.

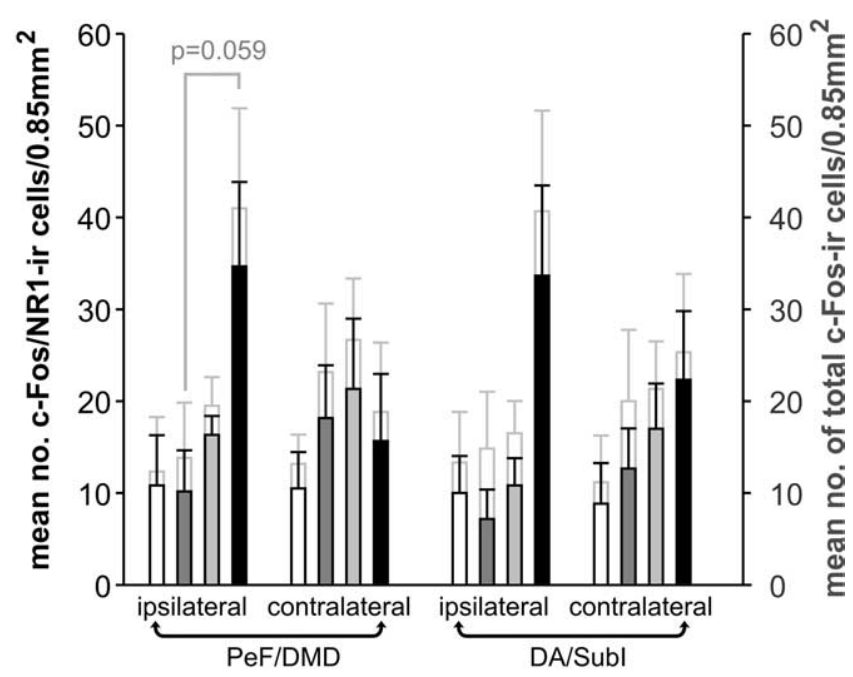

B.

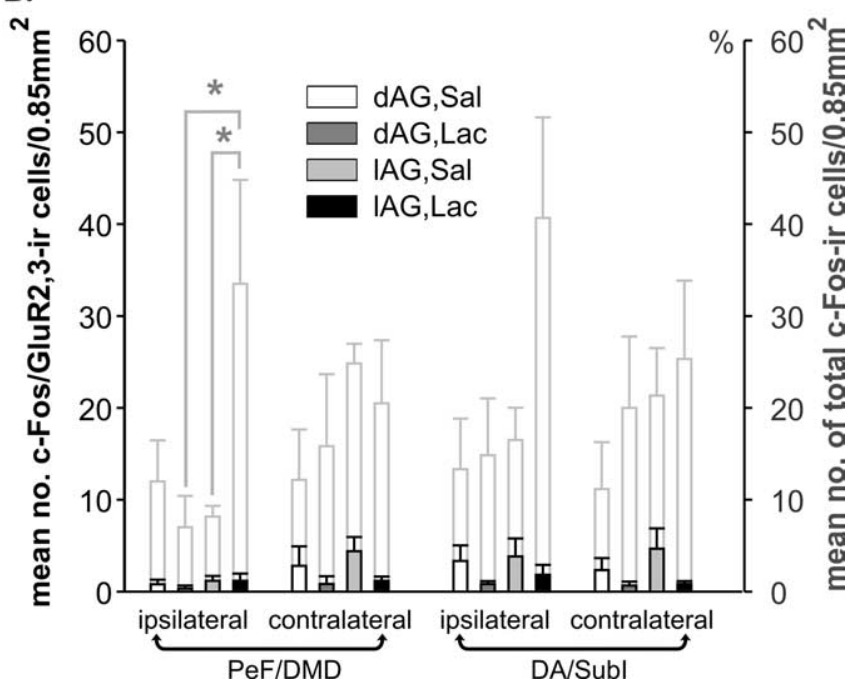

Figure 5. Graphs indicating total numbers of c-Fos-IR cells in dorsal hypothalamic cells and c-Fos-IR cells that expressed either the NMDA or AMPA receptor subunits (NR1 and Glu2/3 receptor subunits, respectively). Shaded bars with black lines represent the number of NR1-IR $(\boldsymbol{A})$ orGluR2/3-IR (B) cells that also expressed c-Fos, and bars with gray lines in $\boldsymbol{A}$ and $\boldsymbol{B}$ indicate the total number of $c-F o s-I R$ cells in each treatment group. These counts were subdivided into the PeF/DMD and DA/Subl regions (see Fig. $3 A$ ) ipsilateral and contralateral to the D-AG or L-AG infusions. ${ }^{*} p<0.05$. f, Fornix; mt, mamillothalamic tract; no., number.

of the DMD most NR1-IR cells were smaller (i.e., $\sim 6-7 \mu \mathrm{m}$ in diameter).

\section{Total c-Fos immunoreactivity}

Although c-Fos immunocytochemistry was done under identical conditions before incubations with the NR1 and GluR2/3 to verify similar numbers of c-Fos-IR cells, we also counted the total number of c-Fos-IR cells in the same areas to verify that the total numbers of c-Fos-IR cells were not significantly different. Comparisons of total numbers of c-Fos from the NR1 and GluR2/3 immunocytochemical studies (using a two-way ANOVA with lactate and isomer as main factors and the immunocytochemical run as a repeated measure) did not reveal significant differences in the total number of c-Fos-IR cells in any region or treatment group (Fig. $5 A, B$ ) [within subjects results: there were no isomer times side $\left(F_{(1,20)}=0.1 ; p=0.803\right)$, lactate times side $\left(F_{(1,20)}=\right.$ $0.7 ; p=0.410)$, or isomer times lactate times side $\left(F_{(1,20)}=0.2\right.$; $p=0.666)$ interactions]. Furthermore, the total numbers of c-Fos in the NR1 and GluR2/3 immunocytochemical run were highly correlated in each of the subregions of the DMH [ipsilateral PeF/DMD $\left(r^{2}=0.80 ; p<0.0001\right)$, contralateral PeF/DMD $\left(r^{2}=0.31 ; p<0.0005\right)$, ipsilateral DA/SubI $\left(r^{2}=0.65 ; p<\right.$ $0.0001)$, and contralateral DA/SubI $\left(r^{2}=0.56 ; p<0.0001\right)$ (data not shown)].

\section{Experiment 2. Effects of glutamate receptor antagonists in the DMH on lactate responses in rats with L-AG pumps in the DMH}

\section{Osmotic minipump probe placement}

Once again, all minipump cannula placements resided in regions of the $\mathrm{DMH}$ and $\mathrm{PH}$ known to be cardioexcitatory and were verified physiologically by injecting BMI under anesthesia and eliciting increases in $\mathrm{HR} \geq 50$ beats/min.

\section{Effects of blocking NMDA receptors in the DMH on intravenous} lactate-induced panic-like response

The overall ANOVA revealed that, when intravenous lactate infusions were given to rats with L-AG Alzet pumps in the DMH after pretreatment with the competitive NMDA antagonist AP-5, there were significant effects of treatment with different doses of AP-5 (Fig. $6 A)$ on $\operatorname{HR}\left(F_{(4,25)}=49.2 ; p<0.001\right), \operatorname{MAP}\left(F_{(4,25)}=\right.$ $7.3 ; p<0.001), \operatorname{RR}\left(F_{(4,25)}=24.0 ; p<0.001\right)$, and SI $\left(F_{(4,25)}=\right.$ $6.8 ; p<0.005)$. There was equal variance among groups for $\mathrm{HR}$

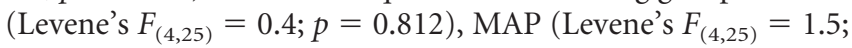
$p=0.238)$, RR (Levene's $F_{(4,25)}=1.7 ; p=0.196$ ), and SI (Levene's $\left.F_{(4,25)}=2.7 ; p=0.053\right)$. In the group that was assigned to be injected with its inactive isomer L-AP-5 at a dose equivalent to the highest dose of AP-5 given (Fig. 6B), sodium lactate induced similar behavioral and physiological responses in L-AG-treated rats $\left[\operatorname{HR}\left(F_{(2,17)}=32.9 ; p<0.0001\right), \operatorname{MAP}\left(F_{(2,17)}=10 / 0 ; p<\right.\right.$ $0.03), \operatorname{RR}\left(F_{(2,17)}=38.3 ; p<0.0001\right)$, and SI $\left(F_{(2,17)}=19.4 ; p<\right.$ $0.001]$. There was equal variance among groups for HR (Levene's $\left.F_{(2,15)}=0.6 ; p=0.580\right), \operatorname{MAP}\left(\right.$ Levene's $\left.F_{(2,15)}=1.3 ; p=0.296\right)$, $\operatorname{RR}\left(\right.$ Levene's $\left.F_{(2,15)}=2.0 ; p=0.169\right)$, and SI (Levene's $F_{(2,15)}=$ $1.1 ; p=0.366)$. Similarly, there were significant effects of treatment with different doses of the noncompetitive NMDA receptor blocker dizocilpine (MK-801) (see Fig. 8) on $\operatorname{HR}\left(F_{(3,20)}=23.7\right.$; $p<0.0001), \operatorname{RR}\left(F_{(3,20)}=19.4 ; p<0.0001\right)$, and SI $\left(F_{(3,20)}=\right.$ $10.2 ; p<0.0001)$, but not on $\operatorname{MAP}\left(F_{(3,20)}=1.5 ; p=0.24\right)$. There was equal variance among groups for HR (Levene's $F_{(3,20)}=0.9$; $p=0.470), \operatorname{MAP}\left(\right.$ Levene's $\left.F_{(3,20)}=2.0 ; p=0.149\right)$, RR (Levene's $\left.F_{(3,20)}=1.8 ; p=0.172\right)$, and SI (Levene's $\left.F_{(3,20)}=1.3 ; p=0.288\right)$.

Post hoc tests in each of these groups revealed that, when these rats were tested at baseline with intravenous lactate infusions, there were no significant changes in $\mathrm{HR}, \mathrm{BP}, \mathrm{RR}$, or SI with lactate infusions before pump implantation (Fig. 6A-C, baseline). After L-AG Alzet pump implantation into the $\mathrm{DMH}$, when these animals were injected with artificial CSF into the DMH and were given intravenous sodium lactate infusions on day 4 , they demonstrated reactivity to intravenous lactate infusions with significant increases in HR, BP, RR, and SI (vehicle plus L-AG; Tukey's post hoc tests; $p<0.05$ ) (Fig. $6 A-C$ ). Preinjection of AP-5 or MK-801 into the $\mathrm{DMH}$, followed by infusion with intravenous sodium lactate, blocked the response to lactate infusions (Fig. $6 A, C$ ) in a dose-dependent manner in all parameters (Tukey's post hoc test; $p<0.05$ between vehicle and AP-5 or MK-801 doses). Preinjection of the highest dose of the inactive isomer L-AP-5 into the DMH, followed by infusion with intravenous sodium lactate, failed to block the response to lactate infusions 

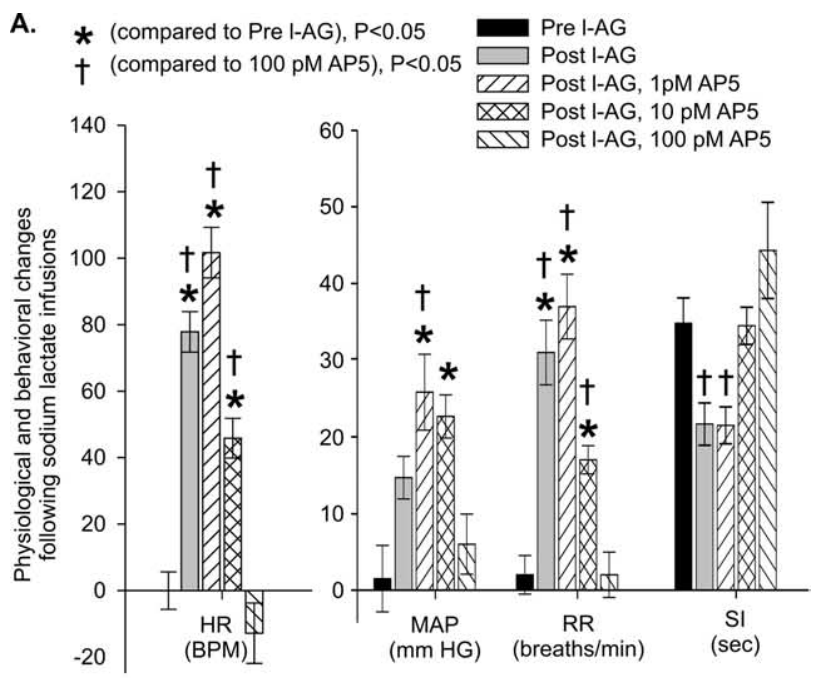

B.
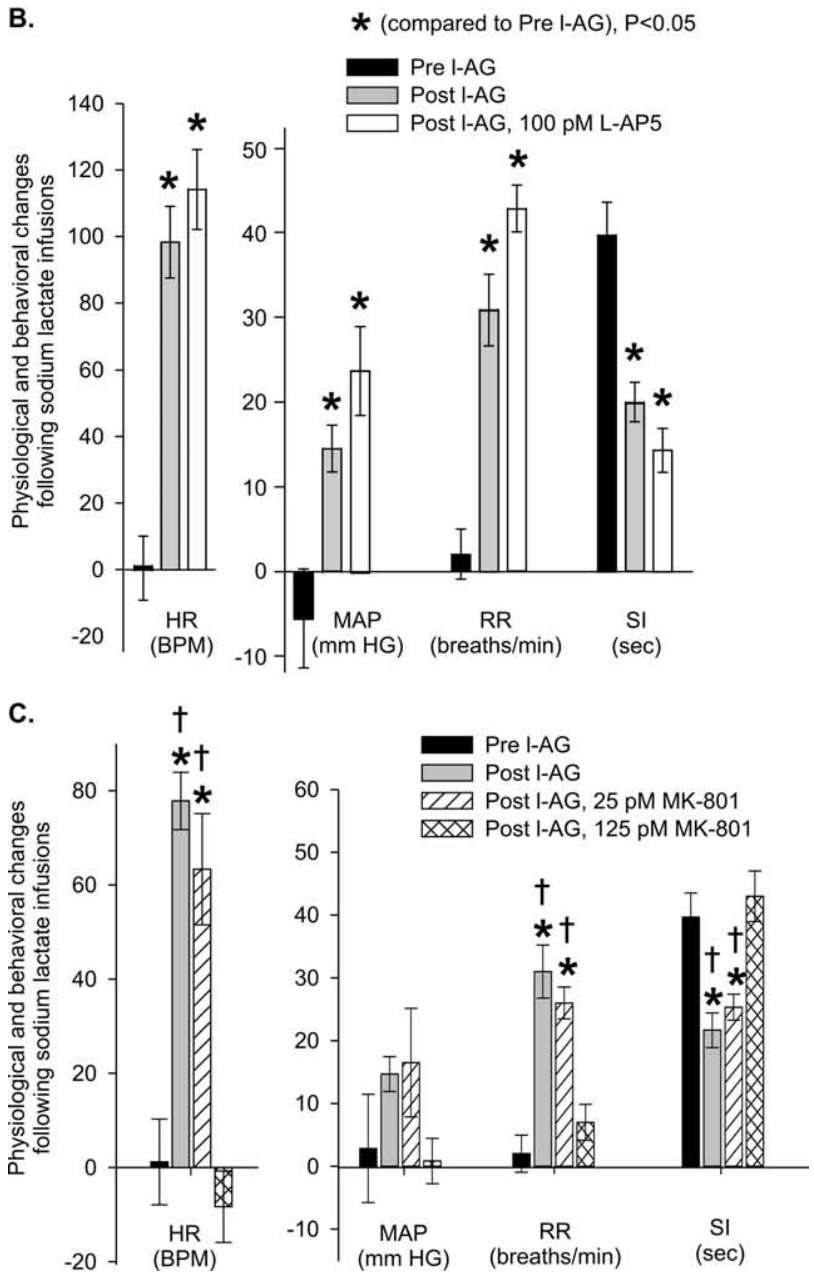

Figure 6. $\quad A$, Changes in HR (beats/min), MAP (in mmHg), RR (breaths/min), and SI time (in seconds) elicited by lactate infusions at baseline (before L-AG pump) and after L-AG pump plus injection of either vehicle (100 $\mathrm{nl}$ ) or the competitive NMDA antagonist AP-5 (1, 10, or $100 \mathrm{pmol})$ into the DMH of rats. Significantly different from ${ }^{*}$ pre-L-AG and ${ }^{\dagger} A P-5(100 \mathrm{pmol}) ; p<0.05 . \boldsymbol{B}$, Changes in HR, MAP, RR, and SI time elicited by lactate infusions at baseline (before L-AG pump) and after L-AG pump plus injection of either vehicle $(100 \mathrm{nl})$ or L-AP-5 (an inactive isomer of AP-5; 100 pmol) into the DMH of rats. Significantly different from *pre-L-AG; $p<0.05$. C, Changes in HR, MAP, RR, and SI elicited by lactate infusions at baseline (before $L-A G$ pump) and after $L-A G$ pump plus injection of either vehicle $(100 \mathrm{nl})$ or the noncompetitive NMDA antagonist MK-801 (25 and $125 \mathrm{pmol}$ ) into the DMH of rats. Significantly different from *pre--L-AG and ${ }^{\dagger}$ MK-801 (125 pmol); $p<0.05$.
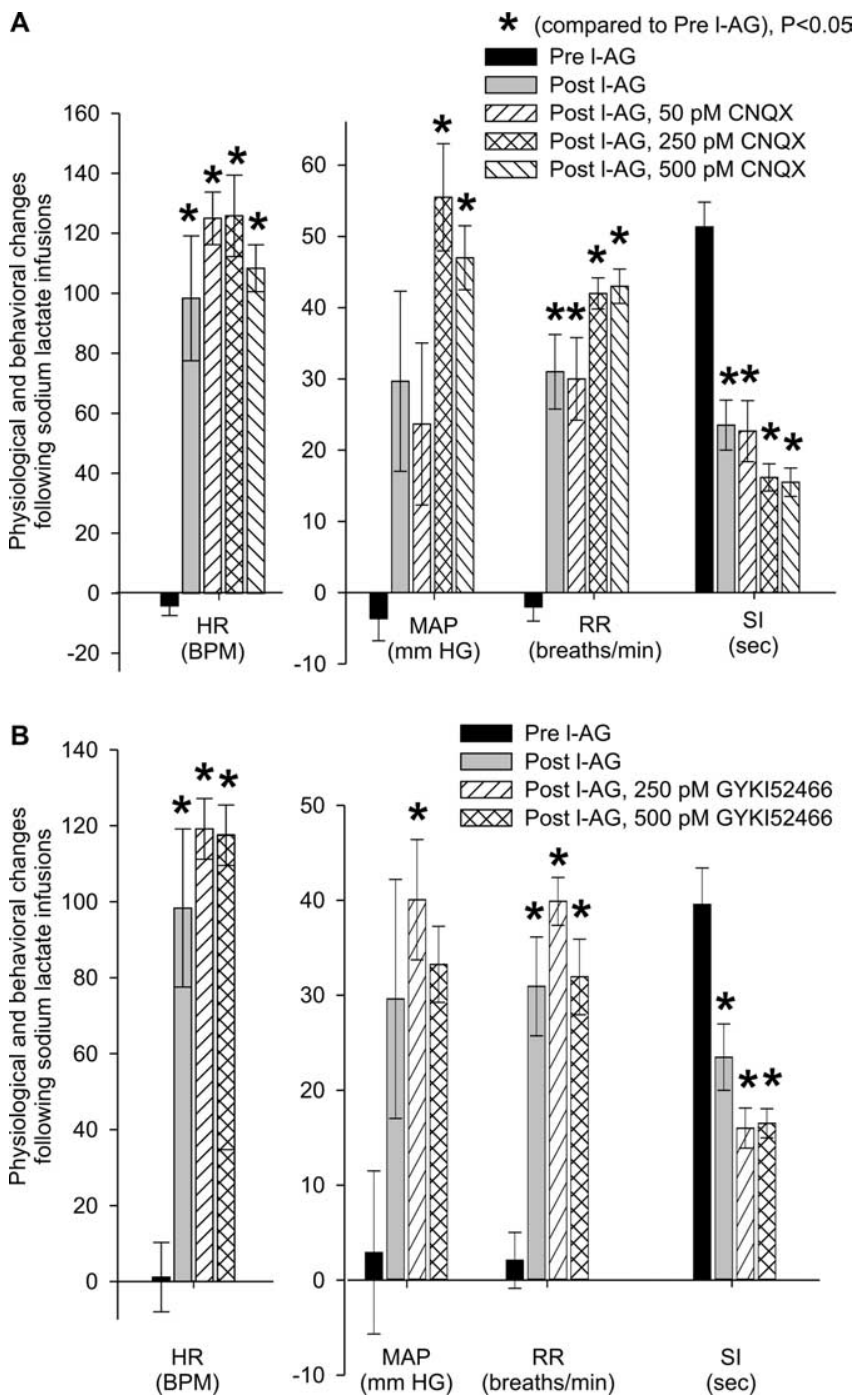

Figure 7. $\quad A$, Changes in HR (beats/min), MAP (in mmHg), RR (breaths/min), and SI time (in seconds) elicited by lactate infusions at baseline (before L-AG pump) and after L-AG pump plus injection of either vehicle (100 nl) or the competitive AMPA antagonist CNQX (50, 250, or 500 pmol) into the DMH of rats. $B$, Changes in HR, MAP, RR, and SI elicited by lactate infusions at baseline (before L-AG pump) and after L-AG pump plus injection of either vehicle ( $100 \mathrm{nl})$ or the noncompetitive AMPA antagonist GYKI52466 (250 and 500 pmol) into the DMH of rats. * Significantly different from pre-L-AG; $p<0.05$.

(Fig. $6 B$ ). Thus blocking NMDA receptors in the DMH clearly blocked the lactate-induced panic-like response in these rats.

Effects of blocking AMPA receptors in the DMH on intravenous lactate-induced panic-like response

The overall ANOVA revealed that there were significant effects of lactate infusions in rats assigned to treatment with different doses of the competitive AMPA receptor antagonist CNQX (Fig. 7A) on $\operatorname{HR}\left(F_{(4,25)}=19.2 ; p<0.0001\right)$, MAP $\left(F_{(4,25)}=7.0 ; p<\right.$ $0.005), \operatorname{RR}\left(F_{(4,25)}=22.0 ; p<0.0001\right)$, and SI $\left(F_{(4,25)}=21.5 ; p<\right.$ 0.0001 ). There was unequal variance among groups for HR (Levene's $\left.F_{(4,25)}=3.3 ; p=0.025\right)$, MAP (Levene's $F_{(4,25)}=5.0 ; p=$ 0.004 ), and RR (Levene's $F_{(4,25)}=3.6 ; p=0.018$ ) but equal variance for SI (Levene's $F_{(4,25)}=1.2 ; p=0.337$ ). Similarly, there were significant effects of lactate infusions in rats assigned to the noncompetitive AMPA receptor antagonist GYKI (Fig. $7 B$ ) on $\operatorname{HR}\left(F_{(3,20)}=19.5 ; p<0.0001\right), \operatorname{MAP}\left(F_{(3,20)}=3.7 ; p<0.05\right), \mathrm{RR}$ $\left(F_{(3,20)}=18.9 ; p<0.0001\right)$, and SI $\left(F_{(3,20)}=14.3 ; p<0.0001\right)$. 
There was equal variance among groups for HR (Levene's $\left.F_{(3,20)}=3.1 ; p=0.050\right), \operatorname{MAP}\left(\right.$ Levene's $\left.F_{(3,20)}=3.0 ; p=0.056\right)$, $\mathrm{RR}$ (Levene's $\left.F_{(3,20)}=1.0 ; p=0.404\right)$, and SI (Levene's $F_{(3,20)}=$ $1.9 ; p=0.165)$. Once again, post hoc tests showed that, when these rats were tested at baseline with intravenous lactate infusions, there were no significant changes in $\mathrm{HR}, \mathrm{BP}, \mathrm{RR}$, or SI with lactate infusions before pump implantation (Fig. $7 A, B$, baseline). After L-AG Alzet pump implantation into the $\mathrm{DMH}$, when these animals were injected with artificial CSF into the DMH and were given intravenous sodium lactate infusions on day 4, they demonstrated reactivity to intravenous lactate infusions with significant increases in HR, BP, RR, and SI (vehicle plus L-AG; Tukey's post hoc tests; $p<0.05$ ) (Fig. $7 A, B$ ). Preinjection of CNQX or GYKI into the DMH, followed by infusion with intravenous sodium lactate, failed to block the response to lactate infusions (Fig. $7 A, B)$ at any of the doses tested in all parameters [Kruskal-Wallis post hoc tests for CNQX (HR, MAP, RR) and Tukey's post hoc tests for GYKI and CNQX (SI); $p<0.05$ between vehicle and drug doses]. Thus blocking AMPA receptors in the DMH failed to block the lactate-induced panic responses in rats with disruption of GABA inhibition in the DMH.

\section{Discussion}

Sodium lactate infusions (intravenously) elicited robust paniclike responses in rats with chronic inhibition of GABA synthesis in the DMH region (i.e., panic-prone rats), once again confirming our previous reports about this animal model of panic disorder (Shekhar et al., 1996; Shekhar and Keim, 1997, 2000). Rats receiving chronic infusions of $\mathrm{L}-\mathrm{AG}$ into the $\mathrm{DMH}$ in experiment 1 had reduced GABA immunostaining restricted to the $\mathrm{DMH}$, as compared with D-AG controls, which was correlated inversely with the duration of social interaction and is consistent with previous studies (Abshire et al., 1988; Shekhar et al., 1996). Immunocytochemical labeling revealed that lactate selectively increased cellular responses (i.e., c-Fos induction) in DMH neurons expressing the NMDA receptor, but not the AMPA receptor, in "panic-prone" rats. Furthermore, cellular responses in NMDA receptor-expressing neurons in the $\mathrm{DMH}$ correlated with changes in HR after sodium lactate. Only a subset of NMDA receptor-expressing cells responded to L-AG plus lactate, implicating them in panic-like responses. The other NMDAexpressing cells could be involved in other functions attributed to the $\mathrm{DMH}$, such as feeding, temperature regulation, and circadian rhythms (Chou et al., 2003; Gooley et al., 2006). One must use caution when interpreting neural circuitry data based on immediate-early gene induction (Morgan and Curran, 1989); therefore, this anatomical finding was confirmed additionally by pharmacological studies in which injecting the selective antagonists of NMDA receptors AP-5 and MK-801, but not vehicle or the selective AMPA receptor antagonists CNQX or GYKI, into the DMH blocked lactate-induced panic responses in a dosedependent manner. This evidence clearly supports not only a role of glutamate mechanism involved the lactate response in rats with GABA dysfunction in the DMH but also a selective role of NMDA receptors in the DMH in mediating the mobilization of panic-like response in these lactate-sensitive rats. A schema describing important sources of GABA and glutamate in the DMH and their hypothetical role is illustrated in Figure 8.

The presence of both NMDA and AMPA receptors in the $\mathrm{DMH}$ is well established by a variety of techniques, including receptor binding (Meeker et al., 1994), electrophysiology (Bailey et al., 2003), and pharmacological studies (Soltis and DiMicco, 1991; Bailey and DiMicco, 2001; Goren et al., 2003) (see also

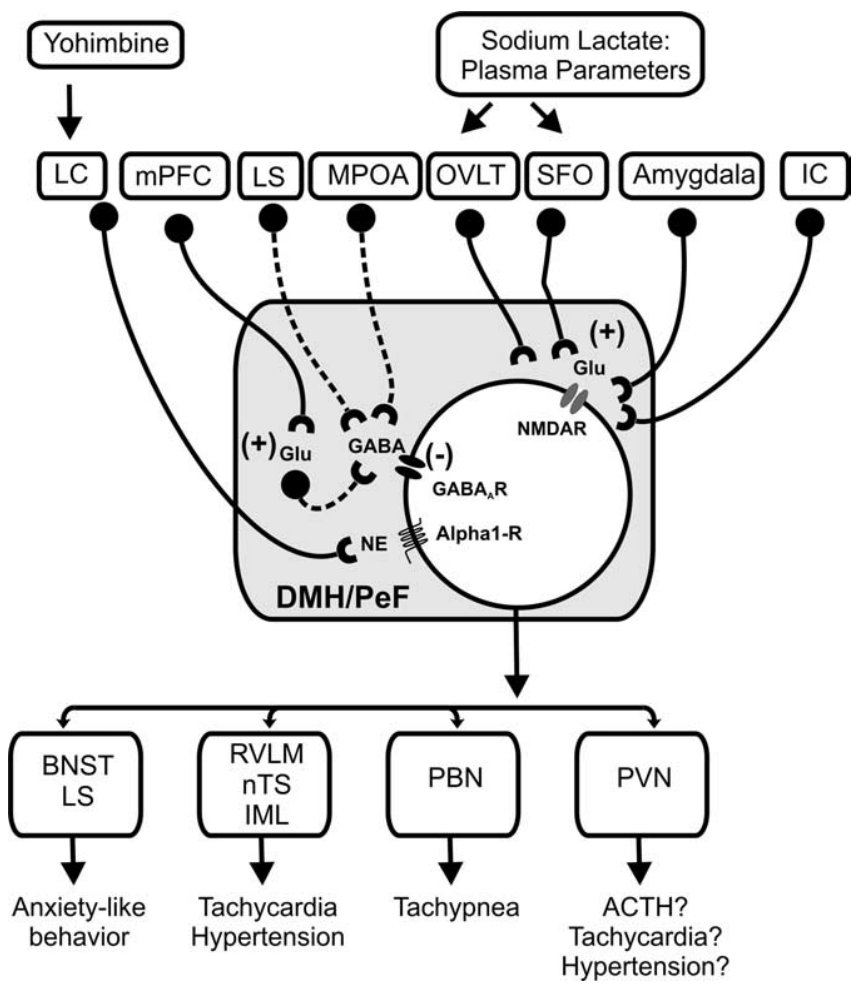

Figure 8. Summary schema of glutamatergic (Glu) and GABAergic input into the DMH/PeF and important efferent brain regions implicated in the regulation of panic-like responses. GABAergic and glutamatergic neurons are represented by circles attached to dashed or solid lines, respectively. Sources of GABA include local interneurons as well as efferent brain regions such as the lateral septum (LS) and medial preoptic area (mPOA) (Feldblum et al., 1993; Risold and Swanson, 1997; Thompson and Swanson, 1998; Herman et al., 2003). This GABAergic input appears to inhibit the DMH tonically, because inhibiting the MPOA increases cellular activity in the DMH (Satoh et al., 2004) and exaggerates cardioexcitatory responses in L-AG plus lactatetreated rats (Shekhar and Keim, 1997); injections of L-AG into the LS also make rats prone to having panic-like physiological responses to intravenous infusions of $0.5 \mathrm{~m}$ sodium lactate ( $\mathrm{S}$. Keim and $A$. Shekhar, unpublished observations). Another well known regulatory afferent of the hypothalamus is the medial prefrontal cortex (mPFC) (Bard, 1928; Bard and Mountcastle, 1948), which innervates the DMH (Vertes, 2004) and appears to inhibit the DMH tonically (Bard, 1928; Bard and Mountcastle, 1948; McDougall et al., 2004), presumably via glutamatergic projections onto local GABAergic interneurons in the DMH, as is the case in the amygdala (Quirk et al., 2003). Glutamatergic input that excites the DMH/PeF region appears to arise from afferent sites such as the CVOs [i.e., OVLT and subfornical organ (SF0) (Richard and Bourque, 1992; Grob et al., 2003)], the amygdala (Soltis et al., 1998), and also the insular cortex (IC) (Cechetto and Chen, 1990; Butcher and (echetto, 1998). Furthermore, systemic injections of yohimbine, which provokes panic attacks in many panic disorder patients, may induce panic-like responses via brain regions such as the DMH, because exposure to stress (Lowry et al., 2003) and fearful stimuli (Shekhar et al., 1994) increases norepinephrine (NE) concentrations in the DMH, and injecting $\alpha 1$-blockers into the DMH of panic-prone rats before yohimbine infusions blocks panic-like responses (Shekhar, unpublished observations). Afferent targets of the DMH that are implicated in the regulation of panic-like responses are listed also (Chamberlin and Saper, 1994; Thompson and Swanson, 1998; Fontes et al., 2001; Chen et al., 2004). BNST, Bed nucleus of the stria terminalis; IML, intermediolateral cell column of spinal cord; LC, locus ceruleus; nTS, nucleus of solitary tract; PBN, parabrachial nucleus; PVN, paraventricular hypothalamic nucleus; RVLM, rostroventrolateral medulla.

Introduction). However, the functional roles of the different glutamate receptors in the DMH appear to be much more complex. The presence of a tonic GABAergic inhibition appears to have a potent modulatory role on the functions of the glutamate receptors. For example, under normal conditions when the tonic GABAergic inhibition is intact in the $\mathrm{DMH}$, reducing glutamate excitation with direct injections of glutamate receptor antagonists into the DMH increases exploratory behavior but has no effect on anxiety-related behavior, as measured by the elevated 
plus-maze test or the Vogel conflict test (Jardim and Guimaraes, 2004). The anxiogenic response noted with chronic disruption of GABA synthesis and hence reduced GABAergic inhibition in the $\mathrm{DMH}$ is blocked by reducing glutamate release with a presynaptic metabotropic receptor agonist (Shekhar and Keim, 2000). The results of the present report demonstrate that the behavioral activation and anxiogenic effects unmasked by chronically reducing the tonic GABAergic inhibition in the $\mathrm{DMH}$ primarily are mediated postsynaptically by the NMDA type glutamate receptors.

In addition to blocking the anxiogenic responses, injections of NMDA antagonists also completely blocked the lactate-induced cardio-respiratory physiological responses, whereas AMPA antagonists had no effects. This is in contrast to the physiological responses elicited by acute GABA blockade in the DMH, where both NMDA and AMPA receptor antagonists are partially effective in blocking the physiological responses (Soltis and DiMicco, 1991), and injection of NMDA and AMPA receptor agonists into the DMH elicits panic-like physiological and behavioral responses (Soltis and DiMicco, 1992). It appears that chronic reduction of GABA inhibition results in long-term adaptation of the glutamate neurotransmission in this region, resulting in a dominance of the NMDA-mediated excitatory neurotransmission. Such a change could be attributable either to plasticity resulting in an enhanced role of NMDA receptors or to a desensitization of the non-NMDA receptor function in the DMH. Such plastic changes in both types of ionotropic glutamate receptors have been reported in the hypothalamus. For example, NR1 subunit expression is increased in the hypothalamus of rats that are prone to sympathoexcitatory responses after the left coronary artery has been ligated to induce heart failure (Li et al., 2003). Similarly, chronic stress and early life adverse events have been shown to increase hypothalamic NMDA receptor subunit expression (Lee et al., 2003). The changes in composition of the NMDA receptor subunits and the receptor efficacy in the hypothalamus also have been reported for a number of other stimuli, such as light and dark cycle (Pennartz et al., 2001), aging (Gore et al., 2002; Miller and Gore, 2002), drug abuse (Zhu et al., 1999), and chronic stress (Ziegler et al., 2005). The changes also could occur in AMPA receptors such that chronic disruption of GABA inhibition could result in desensitization of these non-NMDA receptors. For example, such a mechanism has been reported in the hypothalamic magnocellular neurons regulating oxytocin and vasopressin secretion (Sladek et al., 1998).

Another possibility is that different stimuli may activate only a subset of glutamate receptors in the hypothalamus to elicit the physiological responses in the animal. For example, previous studies have demonstrated that hemorrhagic stimuli activate the hypothalamic vasopressin secretion selectively via the NMDA, and not non-NMDA, glutamate receptors (Yamaguchi and Watanabe, 2002). Similarly, NMDA receptors are implicated in the vasopressin, but not the cardiovascular, responses to hyperosmotic stimuli in the median preoptic regions (Yamaguchi and Watanabe, 2002). Thus lactate challenges in rats with chronic reduction in GABA inhibition in the DMH preferentially could be activating a glutamatergic system that selectively involves the NMDA postsynaptic receptors and not the AMPA receptors.

The data presented here support the working hypothesis that GABAergic dysfunction in the hypothalamus of humans potentially could lead to panic disorder and sensitivity to panic-like responses elicited by chemical challenges such as sodium lactate (Shekhar et al., 2002). Supporting such a hypothesis, panic disorder patients have demonstrated deficits in central GABA concentrations (Goddard et al., 2001) and benzodiazepines, which positively modulate the $\mathrm{GABA}_{\mathrm{A}}$ receptor, attenuate sodium lactate-induced panic-related responses in panic patients (Pohl et al., 1994), and attenuate panic-like responses evoked from either chemical stimulation of the DMH region (Shekhar, 1994) or by intravenous sodium lactate infusions in rats with GABA dysfunction in the DMH region (Shekhar and Keim, 2000). In addition to the DMH, dysfunctional GABA-glutamate tone in the dorsal periaqueductal gray (Jenck et al., 1995) (for review, see Charney and Deutch, 1996) or amygdala (Sajdyk and Shekhar, 2000) (for review, see Shekhar et al., 2003) also has been implicated in the etiology of panic-like conditions. Overall, dysfunctional GABAglutamate tone in these brain regions may contribute to panicprone states.

Within the CNS, GABA counterbalances the actions of glutamate to prevent hyperexcitation of neurons (for review, see Lydiard, 2003) and suggests that glutamate-mediated hyperexcitation may exist in brain regions as the $\mathrm{DMH}$ of panic-prone rats and panic disorder patients. In light of this, there is increasing recognition that glutamatergic mechanisms may be a potential avenue to develop new treatment for anxiety problems such as panic disorder (for review, see Gorman, 2003; Millan, 2003). Some studies have demonstrated that the noncompetitive NMDA antagonist MK-801 (Xie and Commissaris, 1992; Xie et al., 1995), the competitive NMDA antagonist AP-7 (Plaznik et al., 1994), or metabotropic glutamate receptor agonists that reduce glutamate neurotransmission (Helton et al., 1998; Klodzinska et al., 1999; Kellner et al., 2005) reduce anxiety-like and panicassociated behavior in rats. These results and the present results suggest that selective glutamatergic receptor agents may be potential therapeutic strategies in treating panic disorder in humans.

In summary, rats with chronic inhibition of GABA synthesis in the DMH develop panic-like responses after intravenous sodium lactate infusions, a phenomenon similar to patients with panic disorder, as previously reported. Here we demonstrated that lactate-induced responses increased c-Fos immunoreactivity in DMH neurons expressing the NMDA receptor 1 (NR1) subunit, but not those positive for the GluR2 and 3 subunits of the AMPA receptors. We additionally confirmed this pharmacologically, in which injections of NMDA, but not non-NMDA, antagonists into the DMH resulted in dose-dependent blockade of the $\mathrm{HR}, \mathrm{MAP}, \mathrm{RR}$, and SI responses after lactate infusions. These results indicate that NMDA, and not non-NMDA, type glutamate receptors regulate lactate-induced panic-like responses in rats with GABA dysfunction in the $\mathrm{DMH}$.

\section{References}

Abshire VM, Hankins KD, Roehr KE, DiMicco JA (1988) Injection of L-allylglycine into the posterior hypothalamus in rats causes decreases in local GABA, which correlate with increases in heart rate. Neuropharmacology 27:1171-1177.

Bailey TW, DiMicco JA (2001) Chemical stimulation of the dorsomedial hypothalamus elevates plasma ACTH in conscious rats. Am J Physiol Regul Integr Comp Physiol 280:R8-R15.

Bailey TW, Nicol GD, Schild JH, DiMicco JA (2003) Synaptic and membrane properties of neurons in the dorsomedial hypothalamus. Brain Res 985:150-162.

Bard P (1928) A diencephalic mechanism for the expression of rage with special reference to the sympathetic nervous system. Am J Physiol $84: 490-515$.

Bard P, Mountcastle VB (1948) Some forebrain mechanisms involved in the expression of rage with special reference to suppression of angry behavior. Res Publ Assoc Res Nerv Ment Dis 27:362-404.

Bernardis LL, Bellinger LL (1998) The dorsomedial hypothalamic nucleus revisited: 1998 update. Proc Soc Exp Biol Med 218:284-306.

Butcher KS, Cechetto DF (1998) Receptors in lateral hypothalamic area in- 
volved in insular cortex sympathetic responses. Am J Physiol 275:H689-H696.

Cechetto DF, Chen SJ (1990) Subcortical sites mediating sympathetic responses from insular cortex in rats. Am J Physiol 258:R245-R255.

Chamberlin NL, Saper CB (1994) Topographic organization of respiratory responses to glutamate microstimulation of the parabrachial nucleus in the rat. J Neurosci 14:6500-6510.

Charney DS, Deutch A (1996) A functional neuroanatomy of anxiety and fear: implications for the pathophysiology and treatment of anxiety disorders. Crit Rev Neurobiol 10:419-446.

Charney DS, Heninger GR, Breier A (1984) Noradrenergic function in panic anxiety. Effects of yohimbine in healthy subjects and patients with agoraphobia and panic disorder. Arch Gen Psychiatry 41:751-763.

Chen T, Hui R, Dong YX, Li YQ, Mizuno N (2004) Endomorphin 1- and endomorphin 2-like immunoreactive neurons in the hypothalamus send axons to the parabrachial nucleus in the rat. Neurosci Lett 357:139-142.

Chou TC, Scammell TE, Gooley JJ, Gaus SE, Saper CB, Lu J (2003) Critical role of dorsomedial hypothalamic nucleus in a wide range of behavioral circadian rhythms. J Neurosci 23:10691-10702.

DiMicco JA, Abshire VM (1987) Evidence for GABAergic inhibition of a hypothalamic sympathoexcitatory mechanism in anesthetized rats. Brain Res 402:1-10.

DiMicco JA, Abshire VM, Hankins KD, Sample RH, Wible Jr JH (1986) Microinjection of GABA antagonists into posterior hypothalamus elevates heart rate in anesthetized rats. Neuropharmacology 25:1063-1066.

DiMicco JA, Samuels BC, Zaretskaia MV, Zaretsky DV (2002) The dorsomedial hypothalamus and the response to stress: part renaissance, part revolution. Pharmacol Biochem Behav 71:469-480.

Eyigor O, Centers A, Jennes L (2001) Distribution of ionotropic glutamate receptor subunit mRNAs in the rat hypothalamus. J Comp Neurol 434:101-124.

Feldblum S, Erlander MG, Tobin AJ (1993) Different distributions of GAD65 and GAD67 mRNAs suggest that the two glutamate decarboxylases play distinctive functional roles. J Neurosci Res 34:689-706.

File SE (1980) The use of social interaction as a method for detecting anxiolytic activity of chlordiazepoxide-like drugs. J Neurosci Methods 2:219-238.

Fontes MA, Tagawa T, Polson JW, Cavanagh SJ, Dampney RA (2001) Descending pathways mediating cardiovascular response from dorsomedial hypothalamic nucleus. Am J Physiol Heart Circ Physiol 280:H2891-H2901.

Goddard AW, Mason GF, Almai A, Rothman DL, Behar KL, Petroff OA, Charney DS, Krystal JH (2001) Reductions in occipital cortex GABA levels in panic disorder detected with ${ }^{1} \mathrm{H}$-magnetic resonance spectroscopy. Arch Gen Psychiatry 58:556-561.

Gooley JJ, Schomer A, Saper CB (2006) The dorsomedial hypothalamic nucleus is critical for the expression of food-entrainable circadian rhythms. Nat Neurosci 9:398-407.

Gore AC, Oung T, Woller MJ (2002) Age-related changes in hypothalamic gonadotropin-releasing hormone and $\mathrm{N}$-methyl-D-aspartate receptor gene expression, and their regulation by oestrogen, in the female rat. J Neuroendocrinol 14:300-309.

Goren MZ, Yananli HR, Berkman K, Onat F, Aker R (2003) The influence of dorsomedial hypothalamic nucleus on contralateral paraventricular nucleus in NMDA-mediated cardiovascular responses. Brain Res 968:219-226

Gorman JM (2003) New molecular targets for antianxiety interventions. J Clin Psychiatry 64 [Suppl 3]:28-35.

Gorman JM, Papp LA, Coplan JD, Martinez JM, Lennon S, Goetz RR, Ross D, Klein DF (1994) Anxiogenic effects of $\mathrm{CO}_{2}$ and hyperventilation in patients with panic disorder. Am J Psychiatry 151:547-553.

Gorman JM, Kent JM, Sullivan GM, Coplan JD (2000) Neuroanatomical hypothesis of panic disorder, revised. Am J Psychiatry 157:493-505.

Grob M, Trottier JF, Drolet G, Mouginot D (2003) Characterization of the neurochemical content of neuronal populations of the lamina terminalis activated by acute hydromineral challenge. Neuroscience 122:247-257.

Helton DR, Tizzano JP, Monn JA, Schoepp DD, Kallman MJ (1998) Anxiolytic and side-effect profile of LY354740: a potent, highly selective, orally active agonist for group II metabotropic glutamate receptors. J Pharmacol Exp Ther 284:651-660.

Herman JP, Figueiredo HF, Mueller NK, Ulrich-Lai Y, Ostrander MM, Choi DC, Cullinin WE (2003) Central mechanisms of stress integration: hi- erarchical circuitry controlling hypothalamo-pituitary-adrenocortical responsiveness. Front Neuroendocrinol 24:151-180.

Hirschfeld RM (1996) Panic disorder: diagnosis, epidemiology, and clinical course. J Clin Psychiatry 57 [Suppl 10]:3-8.

Jardim MC, Guimaraes FS (2004) Role of glutamate ionotropic receptors in the dorsomedial hypothalamic nucleus on anxiety and locomotor behavior. Pharmacol Biochem Behav 79:541-546.

Jenck F, Moreau JL, Martin JR (1995) Dorsal periaqueductal gray-induced aversion as a simulation of panic anxiety: elements of face and predictive validity. Psychiatry Res 57:181-191.

Katon WJ, Roy-Byrne P, Russo J, Cowley D (2002) Cost-effectiveness and cost offset of a collaborative care intervention for primary care patients with panic disorder. Arch Gen Psychiatry 59:1098-1104.

Kellner M, Muhtz C, Stark K, Yassouridis A, Arlt J, Wiedemann K (2005) Effects of a metabotropic glutamate(2/3) receptor agonist (LY544344/ LY354740) on panic anxiety induced by cholecystokinin tetrapeptide in healthy humans: preliminary results. Psychopharmacology (Berl) 179:310-315.

Kessler RC, McGonagle KA, Zhao S, Nelson CB, Hughes M, Eshleman S, Wittchen HU, Kendler KS (1994) Lifetime and 12-month prevalence of DSM-III-R psychiatric disorders in the United States. Results from the National Comorbidity Survey. Arch Gen Psychiatry 51:8-19.

Klein DF (1993) False suffocation alarms, spontaneous panics, and related conditions. An integrative hypothesis. Arch Gen Psychiatry 50:306-317.

Klodzinska A, Chojnacka-Wojcik E, Palucha A, Branski P, Popik P, Pilc A (1999) Potential anti-anxiety, anti-addictive effects of LY354740, a selective group II glutamate metabotropic receptor agonist in animal models. Neuropharmacology 38:1831-1839.

Lee PR, Brady D, Koenig JI (2003) Corticosterone alters N-methyl-Daspartate receptor subunit mRNA expression before puberty. Brain Res Mol Brain Res 115:55-62.

Li YF, Cornish KG, Patel KP (2003) Alteration of NMDA NR1 receptors within the paraventricular nucleus of hypothalamus in rats with heart failure. Circ Res 93:990-997.

Liebowitz MR, Fyer AJ, Gorman JM, Dillon D, Appleby IL, Levy G, Anderson S, Levitt M, Palij M, Davies SO (1984) Lactate provocation of panic attacks. I. Clinical and behavioral findings. Arch Gen Psychiatry 41:764-770.

Liebowitz MR, Gorman JM, Fyer A, Dillon D, Levitt M, Klein DF (1986) Possible mechanisms for lactate's induction of panic. Am J Psychiatry 143:495-502.

Lowry CA, Plant A, Shanks N, Ingram CD, Lightman SL (2003) Anatomical and functional evidence for a stress-responsive, monoamineaccumulating area in the dorsomedial hypothalamus of adult rat brain. Horm Behav 43:254-262.

Lydiard RB (2003) The role of GABA in anxiety disorders. J Clin Psychiatry 64 [Suppl 3]:21-27.

McDougall SJ, Widdop RE, Lawrence AJ (2004) Medial prefrontal cortical integration of psychological stress in rats. Eur J Neurosci 20:2430-2440.

Meeker RB, Greenwood RS, Hayward JN (1994) Glutamate receptors in the rat hypothalamus and pituitary. Endocrinology 134:621-629.

Millan MJ (2003) The neurobiology and control of anxious states. Prog Neurobiol 70:83-244.

Miller BH, Gore AC (2002) N-methyl-D-aspartate receptor subunit expression in GnRH neuron changes during reproductive senescence in the female rat. Endocrinology 143:3568-3574.

Morgan JI, Curran T (1989) Stimulus-transcription coupling in neurons: role of cellular immediate-early genes. Trends Neurosci 12:459-462.

Pennartz CM, Hamstra R, Geurtsen AM (2001) Enhanced NMDA receptor activity in retinal inputs to the rat suprachiasmatic nucleus during the subjective night. J Physiol (Lond) 532:181-194.

Petralia RS, Yokotani N, Wenthold RJ (1994) Light and electron microscope distribution of the NMDA receptor subunit NMDAR1 in the rat nervous system using a selective anti-peptide antibody. J Neurosci 14:667-696.

Petralia RS, Wang YX, Niedzielski AS, Wenthold RJ (1996) The metabotropic glutamate receptors, mGluR2 and mGluR3, show unique postsynaptic, presynaptic, and glial localizations. Neuroscience 71:949-976.

Plaznik A, Palejko W, Nazar M, Jessa M (1994) Effects of antagonists at the NMDA receptor complex in two models of anxiety. Eur Neuropsychopharmacol 4:503-512. 
Pohl R, Balon R, Bechou R, Lycaki H (1994) Lactate-induced anxiety after imipramine and diazepam treatment. Anxiety 1:54-63.

Quirk GJ, Likhtik E, Pelletier JG, Pare D (2003) Stimulation of medial prefrontal cortex decreases the responsiveness of central amygdala output neurons. J Neurosci 23:8800-8807.

Richard D, Bourque CW (1992) Synaptic activation of rat supraoptic neurons by osmotic stimulation of the organum vasculosum lamina terminalis. Neuroendocrinology 55:609-611.

Risold PY, Swanson LW (1997) Chemoarchitecture of the rat lateral septal nucleus. Brain Res Brain Res Rev 24:91-113.

Sajdyk TJ, Shekhar A (2000) Sodium lactate elicits anxiety in rats after repeated GABA receptor blockade in the basolateral amygdala. Eur J Pharmacol 394:265-273.

Samuels BC, Zaretsky DV, DiMicco JA (2004) Dorsomedial hypothalamic sites where disinhibition evokes tachycardia correlate with location of raphe-projecting neurons. Am J Physiol Regul Integr Comp Physiol 287:R472-R478.

Sanders SK, Morzorati SL, Shekhar A (1995) Priming of experimental anxiety by repeated subthreshold GABA blockade in the rat amygdala. Brain Res 699:250-259.

Satoh S, Matsumura H, Fujioka A, Nakajima T, Kanbayashi T, Nishino S, Shigeyoshi Y, Yoneda H (2004) FOS expression in orexin neurons following muscimol perfusion of preoptic area. NeuroReport 15:1127-1131.

Shekhar A (1993) GABA receptors in the region of the dorsomedial hypothalamus of rats regulate anxiety in the elevated plus-maze test. I. Behavioral measures. Brain Res 627:9-16.

Shekhar A (1994) Effects of treatment with imipramine and clonazepam on an animal model of panic disorder. Biol Psychiatry 36:748-758.

Shekhar A, Katner JS (1995) Dorsomedial hypothalamic GABA regulates anxiety in the social interaction test. Pharmacol Biochem Behav 50:253-258.

Shekhar A, Keim SR (1997) The circumventricular organs form a potential neural pathway for lactate sensitivity: implications for panic disorder. J Neurosci 17:9726-9735.

Shekhar A, Keim SR (2000) LY354740, a potent group II metabotropic glutamate receptor agonist, prevents lactate-induced panic-like response in panic-prone rats. Neuropharmacology 39:1139-1146.

Shekhar A, Katner JS, Rusche WP, Sajdyk TJ, Simon JR (1994) Fearpotentiated startle elevates catecholamine levels in the dorsomedial hypothalamus of rats. Pharmacol Biochem Behav 48:525-529.

Shekhar A, Keim SR, Simon JR, McBride WJ (1996) Dorsomedial hypotha- lamic GABA dysfunction produces physiological arousal following sodium lactate infusions. Pharmacol Biochem Behav 55:249-256.

Shekhar A, Ball SG, Sajdyk TJ, Goddard AW (2002) Neurobiology of panic disorder. Trends Econ Neurobiol 4:36-41.

Shekhar A, Sajdyk TJ, Gehlert DR, Rainnie DG (2003) The amygdala, panic disorder, and cardiovascular responses. Ann NY Acad Sci 985:308-325.

Sladek CD, Badre SE, Morsette DJ, Sidorowicz HE (1998) Role of nonNMDA receptors in osmotic and glutamate stimulation of vasopressin release: effect of rapid receptor desensitization. J Neuroendocrinol 10:897-903.

Soltis RP, DiMicco JA (1991) GABA and excitatory amino acid receptors in dorsomedial hypothalamus and heart rate in rats. Am J Physiol 260:R13-R20.

Soltis RP, DiMicco JA (1992) Hypothalamic excitatory amino acid receptors mediate stress-induced tachycardia in rats. Am J Physiol 262:R689-R697.

Soltis RP, Cook JC, Gregg AE, Stratton JM, Flickinger KA (1998) EAA receptors in the dorsomedial hypothalamic area mediate the cardiovascular response to activation of the amygdala. Am J Physiol 275:R624-R631.

Thompson RH, Swanson LW (1998) Organization of inputs to the dorsomedial nucleus of the hypothalamus: a reexamination with Fluorogold and PHAL in the rat. Brain Res Brain Res Rev 27:89-118.

Vertes RP (2004) Differential projections of the infralimbic and prelimbic cortex in the rat. Synapse 51:32-58.

Weissman MM, Merikangas KR (1986) The epidemiology of anxiety and panic disorders: an update. J Clin Psychiatry [Suppl] 47:11-17.

Xie Z, Commissaris RL (1992) Anxiolytic-like effects of the noncompetitive NMDA antagonist MK-801. Pharmacol Biochem Behav 43:471-477.

Xie ZC, Buckner E, Commissaris RL (1995) Anticonflict effect of MK-801 in rats: time course and chronic treatment studies. Pharmacol Biochem Behav 51:635-640.

Yamaguchi K, Watanabe K (2002) Contribution of N-methyl-D-aspartate receptors in the anteroventral third ventricular region to vasopressin secretion, but not to cardiovascular responses provoked by hyperosmolality and prostaglandin E2 in conscious rats. Brain Res Bull 58:301-309.

Zhu H, Jang CG, Ma T, Oh S, Rockhold RW, Ho IK (1999) Region-specific expression of NMDA receptor NR1 subunit mRNA in hypothalamus and pons following chronic morphine treatment. Eur J Pharmacol 365:47-54.

Ziegler DR, Cullinan WE, Herman JP (2005) Organization and regulation of paraventricular nucleus glutamate signaling systems: $N$-methyl-Daspartate receptors. J Comp Neurol 484:43-56. 